\title{
Are generic and specific adaptation institutions always relevant? An archetype analysis of drought adaptation in Spanish irrigation systems
}

\author{
Sergio Villamavor-Tomas ${ }^{1}$, Irene Iniesta-Arandia ${ }^{1,2}$ and $\underline{\text { Matteo Roggero }}^{3}$
}

\begin{abstract}
The conditions that contribute to institutional robustness of community-based natural resource management (CBNRM) regimes are well understood; however, there is much less systematic evidence regarding whether and how CBNRM regimes adapt to changing environments. We address this question by exploring drought adaptation of 37 irrigation associations in northern Spain. For this purpose, we adopt the distinction between "generic" and "specific adaptation institutions" and explore whether and how these institutions combine across different types of irrigation systems. We obtained data from a survey delivered to the 37 associations, governmental records, and interviews with representatives of the associations and public officials. We then used hierarchical cluster analysis to classify the irrigation systems into types, followed by qualitative comparative analysis to explore associations between the adaptation institutions and drought adaptation across the types of systems. According our results, CBNRM regimes adapt to droughts through different combinations of institutions (i.e., different paths to drought adaptation). However, specific adaptation institutions such as water transfers are more relevant during droughts (i.e., to allocate scarcity), whereas generic adaptation institutions such as monitoring and collective choice arrangements play a role both during and in the aftermath of droughts (i.e., to build compliance with and redesign specific adaptation institutions). Also, we did not find an alignment between the two types of institutions and types of irrigation system; however, one type of system (i.e., the "Asian" type) shows a larger number of drought adaptation paths than the other (i.e., the "American" type).
\end{abstract}

Key Words: adaptation; archetype analysis; common-pool resources; drought; hierarchical cluster analysis; irrigation; qualitative comparative analysis; water user associations

\section{INTRODUCTION}

The relationship between community-based natural resource management (CBNRM) and adaptation is of global concern given the ubiquity of CBNRM worldwide, the impacts of global environmental change at local levels, and the recent calls for the integration of climate and natural resource management policies. Much of what we know about CBNRM addresses the conditions that contribute to sustainable resource use (Ostrom 1990, Agrawal 2001, Stern et al. 2002, Cox et al. 2010); however, much less is known about how CBNRM systems and institutions deal with environmental change and disturbances (Anderies et al. 2004, Murtinho and Hayes 2012). Advancements in these respects are particularly urgent in the context of climate change, which has the potential to disrupt existing CBNRM arrangements unless communities show the capacity to adapt to new conditions. We address this gap by exploring the drought adaptation of 37 irrigation associations in northern Spain.

Two bodies of literature can contribute to a deeper understanding of how CBNRM arrangements adapt to global environmental change: specifically, the literature on institutional change, and the literature on climate adaptation. The former addresses how changing circumstances determine changes in institutions (Hodgson 1998, Acemoglu et al. 2005, Streeck and Thelen 2005, Buchanan et al. 2014). The latter shows how the vulnerability of given social-ecological systems and their capacity to adapt to climate impacts are deeply intertwined with institutions (Adger 2003, Huntjens et al. 2012, Bisaro and Hinkel 2016). Surprisingly though, both bodies of literature provide little insight on the link between global environmental change and CBNRM: the former has focused mostly on institutional determinants other than environmental change (Roggero et al. 2018b), whereas the latter only recently started to introduce the toolbox of institutional analysis (Biesbroek et al. 2014), with little attention to the special case of CBNMR.

Developing theory about the conditions that explain adaptation in CBRNM systems is not an easy task for at least two reasons. First, the study of adaptation needs to address what adaptation means under certain disturbances and for specific types of people and their understandings of success, as well as mobilize theory that applies across contexts (Smit et al. 2000, Carpenter et al. 2001). Here, we focus on a relatively homogeneous type of resource users and a specific disturbance (i.e., irrigation associations and droughts), and irrigation performance as a measure of drought adaptation. We rely on theory (i.e., CBNRM theory) that has been validated with regard to other contexts and environmental problems (Poteete et al. 2010) and build on the distinction between generic and specific adaptation capacity (Lemos et al. 2013). Generic adaptation capacity is associated with fundamental sustainability and human development goals, and specific adaptation capacity is associated with managing and reducing specific threats. Previous studies have used this distinction to explore adaptation trade-offs and the influence of the political and economic contexts on local adaptations (Eakin et al. 2014, Villamayor-Tomas and García-López 2017). Here, we use it to separate institutions generally oriented to maintain cooperation in CNRM regimes at large (generic adaptation institutions such as collective choice and monitoring rules) from those specifically designed to cope with disturbances such as droughts (specific adaptation institutions such as water transfer policies). 
Second, CBRNM theory suffers from a problem of "too many conditions" (Agrawal 2001). More than 30 conditions have been found to explain performance in CBNRM systems (Agrawal 2001), and although it is well understood that different sets of conditions apply in different contexts, it is rather unclear how they do so (Baggio et al. 2016). The "too many conditions" problem reflects a more general concern in the field of environmental social science, which is the need to develop a science of diagnosis that builds and tests contextualized generalizations and transcends the debate between universal generalizations and ideographic explanations (Ostrom 2007, Cox et al. 2016). Against this challenge, we adopt an archetypes approach. Archetype analysis provides a methodological approach to develop middle-range theories rooted in empirical evidence. They specify the range of contexts for which a particular theory or model is expected to be valid, thus helping to overcome the "too many conditions" problem and other issues associated with research fragmentation (Oberlack et al. 2019). Archetypes analysis involves a variety of techniques (Sietz et al. 2019) as well as a set of common choices, challenges, and quality criteria (Eisenack et al. 2019). Here, we rely on two specific techniques, hierarchical cluster analysis (HCA) and qualitative comparative analysis (QCA), in a sequential manner. Specifically, we first rely on HCA to distinguish types of irrigation systems and then use QCA to explore whether and how different combinations of generic and specific adaptation institutions constitute paths to drought adaptation across the types of irrigation systems.

Irrigation systems are one example of CBNRM in many regions around the world (Garces-Restrepo et al. 2007). In Spain, as in many other countries with a significant share of irrigated land, farmers self-organize into water user associations (WUAs) for the allocation of water and infrastructure maintenance at the irrigation system level (Garces-Restrepo et al. 2007). Spain is characterized by the long tradition and autonomy of its WUAs (Glick 1970, Ostrom 1990). Such autonomy is both rooted in customary law and a water use rights system that grants communities of irrigators with the authority to manage collective water use rights within their jurisdictions. Spain is well known for its use of water for economic growth (Cazcarro et al. 2013), and irrigated agriculture is one of economic activities on which the impact of droughts is most evident (Boken et al. 2005). Droughts are one of the main disturbances that have historically shaped the social-ecological dynamics of semiarid and Mediterranean regions (Gómez-Baggethun et al. 2012); however, between 2000 and 2020, a series of severe droughts in Spain has driven concerns about the sustainability of the sector (López Gálvez and Naredo 1997, Vicente-Serrano 2004). Thus, while droughts in Spain are not a new phenomenon, their management still constitutes a challenge because of their increasing unpredictability, recurrence, and severity (Vicente-Serrano et al. 2010). Spanish WUAs have responded with a variety of measures that fit their local contexts (Arriaza et al. 2002, Pujol et al. 2006). However, knowledge about the conditions that make some responses more effective than others across contexts is only rudimentary.

In the theory section that follows, we outline the study of adaptation, introduce the distinction between generic and specific adaptation institutions, and frame the study of types of irrigation systems. In the background section, we introduce the 37 irrigation systems under study, with a focus on the institutions used to manage water and to deal with droughts. We then explain the methods of HCA and QCA and their use to classify irrigation systems into types and to explore pathways to drought adaptation within each type, respectively. In the results section, we present the findings of the HCA and QCA. Finally, we discuss the findings with regard to the distinction of different types of irrigation systems and the relevance of generic and specific adaptation institutions.

\section{THEORY}

\section{The institutional dimension of climate change adaptation}

Climate change adaptation encompasses changes in human practices that are made in anticipation of shifting climatic conditions (Smit and Wandel 2006). Emphasizing change in human practices, adaptation scholars were quick to point out the institutional elements, i.e., regulations, property rights, and other rule arrangements of climate adaptation. Eisenack and Stecker (2012), for instance, call attention to the importance of agency and behavior beyond an exclusive focus on infrastructural solutions. Hinkel and Bisaro (2015) distinguish different approaches to the analysis of climate adaptation, with "institutional analyses" featuring prominently (along with "impact", "behavioral", and "decision" analyses). In their systematic analysis of literature on adaptation referenced by the Intergovernmental Panel on Climate Change, Roggero et al. (2018a) find that institutional analyses (as in Hinkel and Bisaro 2014) represent about one article in three. This is not surprising, given the importance of adaptation for resilience (O'Brien et al. 2009) and adaptive management (Tompkins and Adger 2004), two research fields that are deeply intertwined with institutional analysis (Young 2010).

At a closer look, adaptation research relies on concepts such as vulnerability (Adger 2006), learning (Baird et al. 2014), and barriers (Biesbroek et al. 2014), all of which are concepts that link directly to institutions (Roggero et al. 2018a,b). Access to resources and power relations are key determinants of the way vulnerability arises in the first place (Eakin 2005, Füssel and Klein 2006, O'Brien et al. 2009). The ability to reduce one's vulnerability, in turn, is related to the ability of individuals and communities to act collectively (Adger 2003, Pelling and High 2005). Finally, there is the cognitive dimension of climate adaptation (Grothmann and Patt 2005, Seara et al. 2016) and the role of learning (Baird et al. 2014, Nguyen et al. 2016) in the way that both adaptation problems and solutions are framed (Pahl-Wostl et al. 2008, Cundill 2010).

\section{Generic and specific adaptation institutions and community- based natural resource management}

We focus on the linkage between adaptation, collective action, and institutions. Such a linkage is based on standard institutional economics theory: adaptation measures generate different types of social dilemmas and thus require suitable institutional arrangements in order to be effective (Bisaro and Hinkel 2016, Roggero et al. 2018b, Villamayor-Tomas 2018a). In a nutshell, institutions create adaptation capacity by promoting cooperation, which can be geared to cope with general or specific disturbances (Villamayor-Tomas and García-López 2017).

In the context of CBNRM regimes like those featured by WUAs, institutions can promote generic adaptation capacity by 
promoting cooperation at large, i.e., not tailored to a specific problem or disturbance. Collective choice and monitoring institutions are a paradigmatic example of institutions that can promote generic adaptation capacity. Collective choice institutions facilitate common understanding of problems and the pulling of first-hand and low-cost information about problems and thus have a comparative advantage in devising effective rules and strategies to cope with them (Cox et al. 2010). Such processes can be particularly important in periods of crisis (Villamayor-Tomas 2018a). Similarly, monitoring makes those who do not comply with rules visible to the community, which facilitates the effectiveness of rule enforcement (Cox et al. 2010). In many cases, monitoring emerges at a low cost through informal interactions among resource users. In some cases, monitors such as field guards are also hired. The effectiveness of monitoring depends on how widespread noncompliant behavior is, as well as on the cost-benefit balance for monitors to carry out their duties effectively (Coleman and Steed 2009). Although monitoring may not be always necessary, it can be particularly necessary during periods of crisis because it is precisely during these periods that resource use stakes are the highest (Ostrom 1990, Cox et al. 2014).

Institutions can also promote specific adaptation capacity, i.e., collective behavior that is geared to tackle specific problems. A common adaptation to droughts in irrigation systems is the reduction of collective water needs, which can be promoted via institutions that restrict cropping patterns or water use rights (McCord et al. 2015, Villamayor-Tomas and García-López 2017). Alternatively, or complementarily, institutions may organize the use of new water sources (e.g., wells), the reuse of runoff from drainage systems, or the transfer of water from other systems (Chong and Sunding 2006).

\section{Archetypes of irrigation systems}

The arrangements through which WUAs around the world can successfully self-organize to ensure irrigation management takes place can vary significantly (Ostrom 1990, Tang 1992, GarcesRestrepo et al. 2007). A popular distinction separates the Asian from the American type of irrigation systems (Meinzen-Dick et al. 1994). The Asian type tends to be associated with small irrigation systems and organizations. Key irrigation management operations such as decision making, monitoring, and sanctioning are embedded in members' daily interactions and knowledge of each other. Also, organizations tend to be informal: there is low specialization, and coordination is emergent rather than planned. The systems usually fall within the boundaries of small population centers (e.g., villages), include relatively small land holdings, are exposed low market penetration, and contain minor infrastructure (for irrigation as well as for transport and communications).

The American type of irrigation system corresponds with larger organizations and systems. Irrigation management is more professionalized and tends to rely less on face-to-face interactions between farmers. The boundaries of systems tend to be designed according to hydraulic rules and therefore overlap (rather than match) multiple socio-political boundaries. Formal rules and supervisory bodies form the basis for decision making, monitoring, and sanctioning. This type of system is adapted to situations of larger land holdings, greater market development, and more developed physical infrastructure.
Government intervention in the irrigation sector and economic globalization have driven the professionalization and scaling up of irrigation, i.e., a transition from the Asian to the American type in many WUAs worldwide (Garces-Restrepo et al. 2007). Despite this transition, the distinction is still quite patent in many countries and potentially illustrates the existence of different paths to adaptation (Trawick 2003, Lam 2006, Palerm Viqueira 2008).

\section{BACKGROUND: THE RIEGOS DEL ALTO ARAGON PROJECT}

The irrigation systems under study belong to the Riegos del Alto Aragon (RAA) project, which is located in northeastern Spain and expands throughout the Gállego and Cinca River basins, mostly within the province of Huesca (region of Aragon; see Fig. A1 in Appendix 1). The Pyrenees mountain range, which is located at the north of the irrigable area, supplies most of the available water through snowmelt because precipitation in the area is limited to roughly $350 \mathrm{~mm}$ annually and groundwater is almost inexistent in the irrigable area. Approximately $66 \%$ of the available water in the province of Huesca is used in the agricultural sector, which makes the allocation of the Pyrenees' water a crucial task to guarantee agricultural production. The RAA project relies on a series of reservoirs, located in the Gállego and Cinca basins, that deliver water to the systems via a network of main and minor canals. Since the 1980s, the area has suffered from a negative precipitation trend (López-Moreno et al. 2010) and increased climatic uncertainty caused by rapid changes between wet and dry periods (Vicente-Serrano and Cuadrat-Prats 2007). One of the most salient events featuring these trends was the drought that took place between 2005 and 2006. Water availability in 2005 dropped by $60 \%$ compared to the average availability from 1970 to 2003 and was $55 \%$ less than the sum of water use rights in the area. In 2006, water availability was 30\% lower than the 1970 2003 average and more than $20 \%$ less than the sum of water use rights. By 2007, water entries were not significantly different than the 1970-2003 average (see Table A1.1 in Appendix 1; VillamayorTomas 2014a).

\section{Water management institutions}

Irrigation water in Spain is managed by WUAs via a variety of institutions. Farmers who extract water from river weirs or wells are entitled to collective use rights and have to self-organize into a WUA to manage it. The right of water use is proportional to the irrigable area of the system. In turn, associations sharing a water source such as a dam or an entire river or aquifer can form a higher level organization to allocate the water from that source among them. The irrigation systems in the RAA project are coordinated by a General Association of Riegos del Alto Aragon (GCRAA).

Water is allocated across the irrigation systems according to a water request system: WUAs request water from the GCRAA, and then the water is delivered in a coordinated fashion across the systems. Within the systems, water is also allocated through a request system (farmers request and the WUA allocates) or just metered as farmers use it (i.e., if the system counts on pressurized systems with sufficient carrying capacity to serve multiple farmers at the same time). By default, there is no limit to the amount of water that farmers and associations can request during normal water availability conditions. 
WUAs have to include a general assembly and also an executive committee, a president, a secretary, and a conflict-solving committee. The associations can also employ a field guard to monitor the water allocation process. General assemblies are celebrated at the start and end of the irrigation campaign; however, ad hoc extraordinary assemblies are also set to deal with water management issues such as droughts, pollution externalities, or problems with infrastructure investments. Similarly, the intensity of monitoring varies across irrigation campaigns depending on whether WUAs expect or are confronted with water management issues such as canal breakages or water misuse (Villamayor-Tomas 2018a).

Additionally, the GCRAA and WUAs implement a quota policy specifically designed to deal with droughts in which WUAs receive a fixed amount of water depending on the amount of area irrigated and the history of use (Villamayor-Tomas 2014a). In many WUAs, farmers are also allocated a quota based on the amount of area irrigated. Systems can neither go over their quotas nor have access to the quotas of other systems, even if those quotas are underused. However, farmers can transfer their proportional share of a system's quota from one system to another if they own land in both systems. The transfer has to be requested from the GCRAA by the farmer at the beginning of the irrigation campaign and is measured by the amount of area to be irrigated in the receiving system. Once the request is approved, it holds for the entire irrigation campaign. Also, although the quota policy is implemented in all irrigation systems (i.e., it is a constant across the systems), the transfer institution is used to a different degree across the systems.

\section{METHODS}

Because of the large number of conditions potentially relevant for CBNRM, we approach the analysis through archetypes. There are different ways of understanding archetype analysis (Oberlack et al. 2019); we rely on two of them. First, we adopt an "archetypes as typology of cases" (Oberlack et al. 2019) approach to identify types of irrigation system. Here, we follow the approach of studies such as that of Václavík et al. (2013), who identify land system archetypes based on similarities and differences in land systems in terms of land use intensity, social-ecological conditions, and land-change trajectories. Sietz et al. (2017) use a similar exercise to understand the heterogeneity of farming systems' vulnerability and potential for intensification in sub-Saharan Africa. In these studies, cases are classified into one archetype or another depending on their fit with the ideal representation of the archetype. The archetypes, in turn, are profiled based on the distribution of features across the cases and the goal of maximizing the similarity of cases within each archetype. Second, we adopt the "building-blocks" approach to archetype analysis to identify paths to drought adaptation. Paths are here understood as configurations of factors that lead to an outcome through a process (Oberlack et al. 2019). We thus follow the approach of studies such as that of Oberlack et al. (2016), who identify archetypical processes that explain how large-scale land acquisitions affect rural livelihoods, and Oberlack and Eisenack (2018), who use a similar exercise to explain the emergence of barriers to adaptation in the context of river basin management.

The analysis unfolded into two stages. We first ran an HCA to identify types of irrigation systems according to biophysical, technical, social-political, and institutional conditions relevant to the operations of irrigation systems (see Tables A1.2 and A1.3 in Appendix 1). We used an agglomerative technique to build the clusters, where pairs of clusters were combined according to a measure of dissimilarity between sets of observations. We used Bray and Curtis (1957) dissimilarity and Ward's (1963) linkage criterion to identify relatedness among irrigation systems. To characterize the resulting clusters (i.e., types of irrigation systems) and identify the key differences among them, we conducted chisquared tests for the dummy variables and comparison of means and ranks, and Tukey's and Dunn's post-hoc multiple comparisons for quantitative conditions once we had confirmed that significant differences existed among the clusters to determine which clusters differed.

We then ran a QCA to explore paths to drought adaptation. In QCA, outcomes are explained by looking at multiple configurations of factors rather than at individual causes (Ragin 2000), which is particularly appropriate in the study of complex social-ecological processes such as those involving adaptation (Lam and Ostrom 2010). Configurations are understood here as paths to the extent that they reflect particular processes about how different institutions jointly promote cooperative behavior for adaptation (Rihoux and Ragin 2009). From an analytical point of view, QCA tests whether different configurations of multiple conditions co-occur in a systematic way with a particular outcome. Resting on the concept of equifinality, it allows the same phenomenon to be linked to different explanations, each one representing a different combination of causal factors. Furthermore, QCA was designed for case-oriented rather than variable-oriented research (Ragin 2005): in a nutshell, it relies on in-depth case-level knowledge rather than (a large number of) data points. It therefore allows the analysis of a comparatively small number of cases (Vis 2012), which reflects well the conditions of our study.

Variable selection for the HCA (see Table A1.2 in Appendix 1) was informed by the Asian-American distinction theory (Meinzen-Dick et al. 1994), existing literature about irrigation management in the area and elsewhere (Meinzen-Dick 2007, Lecina et al. 2010, Gil Sevilla et al. 2013, Villamayor-Tomas $2014 a, 2018 b$ ), and background knowledge gained through previous research in the area (see Background: the Riegos del Alto Aragon Project). The selection of adaptation institutions for the QCA was based on the details of the RAA project case. Data for the cluster analysis and QCA were collected via a survey sent to representatives of the WUAs, and from records from the GCRAA and the Aragon regional government (see Table A1.2 in Appendix 1). The survey was first sent via email to the Secretaries of the WUAs and then administered by phone for those who had not replied to the email (see Box A1.1 in Appendix 1 for details of the survey). Eight semistructured interviews were also conducted with officials from the GCRAA and the water agency to fill knowledge gaps before and after data collection (see Box A1.2 in Appendix 1). Also, spatial and statistical data obtained from the Ebro Basin Water Agency were used to compute the outcome of the QCA, i.e., drought adaptation.

Drought adaptation was assessed as the difference between irrigation performance in 2004 (a nondrought year) and 2005 (a severe drought year). Irrigation performance was calculated as a 
Fig. 1. Map and dendrogram showing the spatial distribution of the water user associations (WUA) and the clusters obtained through the hierarchical cluster analysis (HCA)
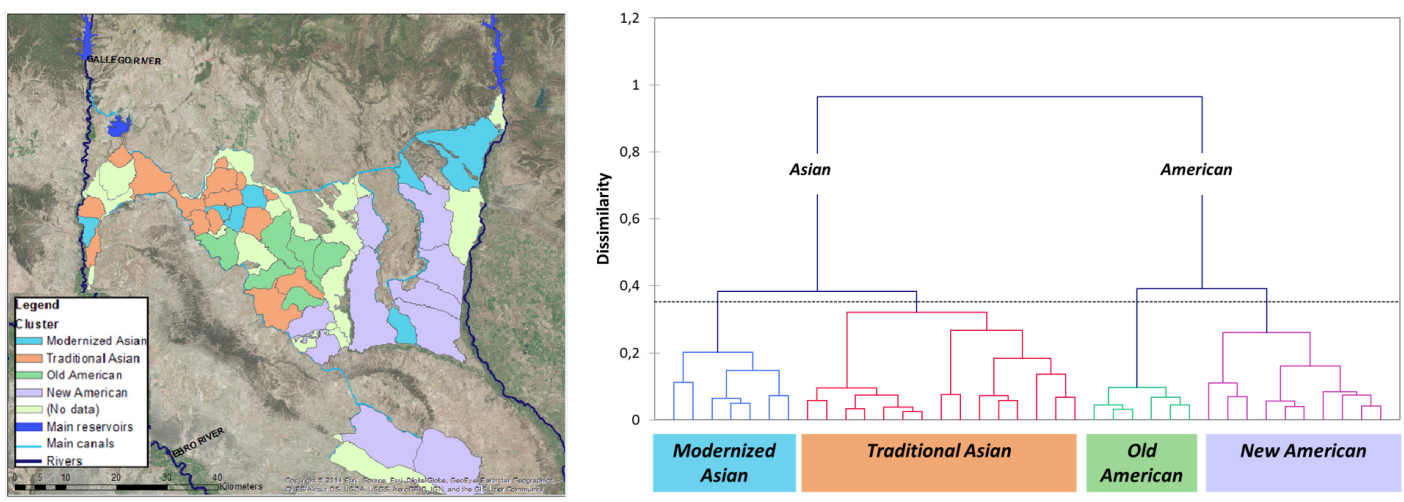

ratio between the water that is supplied to a system and the water that the system needs according to the crops that are planted (see Box A1.3 in Appendix 1; Salvador et al. 2011). Decreases in irrigation performance $>25 \%$ were considered indicative of unsuccessful drought adaptation; decreases in performance < $25 \%$ were considered indicative of successful drought adaptation (see Appendix 2 for details). The adaptation institutions included in the QCA were: "transfers", expressing whether $>3 \%$ of a system's surface area received inflows from other systems during the 2005 drought; "monitoring", expressing whether the WUA reinforced monitoring during droughts; and "participation", expressing whether farmers representing $>50 \%$ of the system's surface area attended the ordinary and extraordinary meetings held during 2005. Based on the reviewed theory, participation and monitoring were used as proxies of generic adaptation institutions, and transfers represented a paradigmatic example of a specific adaptation institution (i.e., in the RAA project).

To address the interplay between archetypes of irrigation system and paths to successful (drought) adaptation, we included a "cluster" attribute based on results from the cluster analysis (see Results for details). This inclusion corresponds, in a simplified way, to a two-step QCA, as proposed by Schneider and Wageman (2006). Ideally, the archetypes of irrigation system correspond to "remote conditions", whereas the adaptation institutions tested correspond to "proximate" ones. Because all cases analyzed here either belong to one or the other archetype, it was not necessary to run separate analyses for each archetype. This factor allowed us to explore whether there were paths to drought adaptation that were common to both archetypes (i.e., not exclusive to either of them).

To carry out the analysis, we used $\mathrm{R}$ version 3.4 .4 (2018-03-15) and, specifically, the "QCA" (Thiem and Dusa 2013) and "SetMethods" (Medzihorsky et al. 2016) packages. Following standard procedure (Schneider and Wagemann 2010), the QCA assessed whether any of the three institutions, alone or in combination with each other, was individually necessary or sufficient for successful drought adaptation and for unsuccessful drought adaptation.

\section{RESULTS}

\section{Identification and characterization of irrigation system archetypes}

The HCA resulted in four WUA archetypes (Fig. 1 and Table 1). The choice of number of clusters was based on two criteria: (1) statistical differences among the clusters as assessed through ranks, means, and chi-squared tests; and (2) the fit between the clusters and our own knowledge of the cases (Iniesta-Arandia et al. 2014, Martín-López et al. 2017). A detailed look at Table 1 illustrates the conditions that play a major role discriminating the archetypes. Relevant physical and technological conditions included the size of the systems, the relative dominance of summer crops (i.e., high water demand) over winter crops, the reliance on piped ditches and sprinkler irrigation, and the degree of heterogeneity with respect to the use of sprinkler irrigation. Important socio-political conditions included the age of the WUA, the average size of farm plots in the system, the amount of land cultivated by retired farmers, whether the system overlaps more than one municipality, and the extent to which the land of the systems is distributed across municipalities. Relevant institutional conditions included whether water is allocated via a command system or farmers can withdraw water at any time.

The archetypes can be understood through the lens of the Asian vs. American distinction. We found two archetypes that relate to the Asian model and two to the American model. Most of the WUAs fitting the "traditional Asian" archetype (Fig. 1) are relatively old (average of $56 \mathrm{yr}$ ), relatively small and fragmented, and have a relatively low degree of technification, technical heterogeneity, and political heterogeneity (just 5 of the 15 irrigation systems in this archetype expand beyond the boundaries of one municipality). Retired farmers are relatively abundant, and mutual monitoring is more frequent than third party monitoring ( 6 of the 15 WUAs in this archetype do not have guards). All of these features tend to align with the Asian ideal type described in the literature. Indeed, many of the WUAs from this archetype correspond to traditional irrigation systems that were incorporated in the RAA project in its early stages. These historical systems had emerged around small villages and along small rivers within the area, and many were located near the head 
Table 1. Characterization of the main archetypes of irrigation systems obtained through hierarchical cluster analysis.

\begin{tabular}{|c|c|c|c|c|c|c|}
\hline Type of variable & Variable & $\begin{array}{c}\text { Modernized } \\
\text { Asian }\end{array}$ & $\begin{array}{c}\text { Traditional } \\
\text { Asian }\end{array}$ & $\begin{array}{c}\text { Old } \\
\text { American }\end{array}$ & $\begin{array}{c}\text { New } \\
\text { American }\end{array}$ & Test statistic \\
\hline \multirow[t]{2}{*}{ Biophysical } & Irrigable area $(\mathrm{ha}) * *$ & $1450 \mathrm{~b}, \mathrm{c}^{\dagger}$ & $1437 \mathrm{~b}$ & $2527 \mathrm{~b}$ & $4552 \mathrm{a}$ & ANOVA $F=12.01$ \\
\hline & Summer crops ( $\%$ of total ha)* & 77 & 70 & 80 & 79 & Kruskal-Wallis $\chi^{2}=8.34$ \\
\hline \multirow[t]{3}{*}{ Technical } & Sprinkler irrigation $(\% \text { of total ha })^{* *}$ & $22 \mathrm{a}, \mathrm{b}$ & $1 \mathrm{~b}$ & $3 \mathrm{~b}$ & $64 \mathrm{a}$ & Kruskal-Wallis $\chi^{2}=26.30$ \\
\hline & Piped canals $(\%$ of total ha)** & 100 & 0 & 0 & 80 & Chi-squared test $\chi^{2}=31.30$ \\
\hline & Technology heterogeneity (index)* & 0.34 & 0.14 & 0.05 & 0.26 & Kruskal-Wallis $\chi^{2}=9.64$ \\
\hline \multirow[t]{5}{*}{ Sociopolitical } & Age of water user association $(\mathrm{yr})^{* *}$ & $45.1 \mathrm{~b}, \mathrm{c}$ & $56 \mathrm{c}$ & $25.5 \mathrm{a}, \mathrm{b}$ & $17.3 \mathrm{a}$ & Kruskal-Wallis $\chi^{2}=27.37$ \\
\hline & Retired farmers ( $\%$ of total ha)* & $30 \mathrm{a}$ & $24 \mathrm{a}, \mathrm{b}$ & $19 \mathrm{~b}$ & $18 \mathrm{~b}$ & ANOVA $F=4.22$ \\
\hline & Average farm size (ha)** & $16.58 \mathrm{a}, \mathrm{b}$ & $14.04 \mathrm{a}$ & $17.09 \mathrm{a}, \mathrm{b}$ & $23.63 \mathrm{a}$ & ANOVA $F=5.43$ \\
\hline & Political overlap ( $\%$ of cases)* & 29 & 33 & 100 & 70 & Chi-squared test $\chi^{2}=10.48$ \\
\hline & Political heterogeneity (index)* & $0.19 \mathrm{a}, \mathrm{b}$ & $0.14 \mathrm{a}$ & $0.49 \mathrm{~b}$ & $0.28 \mathrm{ab}$ & Kruskal-Wallis $\chi^{2}=8.20$ \\
\hline \multirow[t]{4}{*}{ Institutional } & Rent ( $\%$ of total ha) & 31 & 43 & 41 & 43 & Kruskal-Wallis $\chi^{2}=4.63$ \\
\hline & Property heterogeneity (index) & 0.42 & 0.44 & 0.44 & 0.48 & Kruskal-Wallis $\chi^{2}=5.30$ \\
\hline & Demand irrigation ( $\%$ of cases) $)^{* *}$ & 28 & 0 & 0 & 40 & Chi-squared test $\chi^{2}=9.21$ \\
\hline & Guard $(\%$ of cases $) *$ & 57.1 & 66.6 & 100 & 100 & Chi-squared test $\chi^{2}=7.63$ \\
\hline
\end{tabular}

of the project. Once incorporated to the project, they maintained their original institutions to manage the new canal water.

Systems and WUAs corresponding to the "modernized Asian" archetype are relatively similar to those fulfilling the traditional Asian archetype. They are similar with regard to most of the relevant features, and many also share a similar history. However, they differ with regard to technical features (reliance on piped ditches and sprinkle irrigation) and, to a lesser extent, institutional conditions (demand irrigation). These differences can be explained by the infrastructure (i.e., pressurized irrigation) investments that many of the modernized Asian WUAs have accomplished since 2000. In the early 2000's, in a context of recurrent droughts and increased competition over water resources, the Spanish and regional governments initiated an ambitious program of subsidies to stimulate investments in infrastructure that boosted water efficiency and conservation in the sector (Lecina et al. 2010, López-Gunn et al. 2013). The modernized Asian WUAs responded positively to those stimuli. Many WUAs used the funds to install pressurized irrigation so that farmers could switch to sprinkler irrigation in their plots.

Alternatively, the "new American" archetype is characterized by relatively new WUAs (17 yr old on average), large systems and plots, a high degree of technification and technical heterogeneity, and, to a lesser extent, a comparably low proportion of land cultivated by retired farmers and a high reliance on guards for monitoring (all WUAs). All of these features tend to align with the American ideal type described in the literature. Many of the WUAs belonging to the new American archetype correspond to the last wave of systems that were created in the project in the late 1970s and early 1980s. By this time, irrigation technology had made considerable progress, and many of the new systems included pressurized irrigation and, in some cases, piped canals. Also, importantly, many of the systems were created in areas relatively far from rivers and streams and following the limits of relatively large hydraulic sectors (sections of the main canal), rather than according to political boundaries (as in the case of traditional and modernized Asian WUAs). The new American WUAs are similar to the modernized Asian ones in their technical features; however, the history of each group of WUAs is different, as the latter have had to adjust their management to the new technology, whereas the former were created to use pressurized irrigation.

The "old American" archetype is more similar to the new American archetype than to any of the other archetypes and, therefore, is also more similar to the American than the Asian ideal type. As in the case of traditional and modernized Asian WUAs, the differences between the old and new American WUAs have to do with technological aspects, as well as history. Contrary to the new American WUAs, the old American WUAs were created at a time (late 1960s, early 1970s) when pressurized irrigation was not considered by the project planners as an option. Many of those systems were therefore built to satisfy flood irrigation (in most cases via small irrigation aqueducts and paved ditches).

\section{Paths to successful drought adaptation}

Given the similarity of the two Asian archetypes and the two American archetypes, we collapsed them into two archetypes: Asian archetype WUAs and American archetype WUAs. This allowed the creation of a binary cluster condition $(1=$ Asian archetype WUAs). Nine of the 16 American WUAs (56\%) and 11 of the 21 Asian WUAs (52\%) displayed successful drought adaptation.

According to the analysis of necessity, none of the three institutions or the cluster attribute is necessary for successful drought adaptation. Conventionally, they should appear in at least $90 \%$ of the cases in which the outcome is observed to be necessary. Here, the institution most consistently co-occurring with the outcome is transfers, which is present in $58 \%$ of successful drought adaptation cases. This implies that $42 \%$ of successful adaptation cases do not particularly rely on transfer inflows; thus, it clearly cannot be necessary for successful drought adaptation. Similar considerations hold for the other institutions, with the same or even lower consistency scores.

According to the analysis of sufficiency, there are five paths to successful drought adaptation. The overall consistency of the 
solution is 0.923 , meaning that $>90 \%$ of cases profiling any of the paths also display successful drought adaptation. This, however, does not mean that all successful drought adaptation cases fall into one of the five paths. There are seven successful cases that illustrate other paths, but these paths are not as recurrent as the five recognized paths. The five paths cover $63 \%$ of successful drought adaptation cases (see Table 2), which, from a QCA perspective, corresponds to a coverage score of 0.63 . A coverage score $<1$ is not problematic and simply implies that successful drought adaptation can be brought about through paths other than the five identified.

Table 2. Necessity scores for successful and unsuccessful drought adaptation.

\begin{tabular}{lcc}
\hline \hline $\begin{array}{l}\text { Institution or } \\
\text { variable }\end{array}$ & $\begin{array}{c}\text { Successful drought } \\
\text { adaptation }\end{array}$ & $\begin{array}{c}\text { Unsuccessful drought } \\
\text { adaptation }\end{array}$ \\
\hline Transfers & 0.579 & 0.389 \\
Participation & 0.368 & 0.611 \\
Monitoring & 0.263 & 0.278 \\
Cluster & 0.579 & 0.556 \\
\hline
\end{tabular}

One of the five paths of successful drought adaptation is independent of whether the WUAs belong to the Asian or American archetypes. It encompasses four WUAs characterized by transfer inflows, strengthened monitoring, and lack of participation (Table 2). A closer look, however, reveals that three of these WUAs belong to the American archetype, and only one corresponds to the Asian archetype.

The other four paths are contingent on whether the WUA belongs to the Asian or American archetype. Of the two Asian paths, one features transfer inflows and strengthened monitoring (two cases), whereas the other is characterized by the absence of all adaptation institutions (three cases). Together, these two archetypes cover just less than half of the 11 successful adaptation cases of the Asian archetype. The American paths both profile the presence of transfer inflows; one of them is also associated with the absence of participation, and the other is associated with the absence of strengthened monitoring. They respectively cover six and four of the nine successful cases within the American irrigation archetype (one of the cases fits both paths).

Compared to the paths in the Asian archetype, those in the American archetype have better coverage ( 0.75 and 0.5 compared to 0.18 and 0.27 , respectively), but slightly lower consistency $(0.86$ and 0.8 compared to 1 and 1 , respectively). Given this difference in coverage, and considering that the cluster-independent archetype is predominantly American, one may conclude that the adaptation institutions under study have more explanatory capacity within the American than the Asian irrigation archetype.

According to the analysis of necessity for unsuccessful drought adaptation, none of the studied institutions is necessary (Table 3). The closest institution to be so is participation, which is present in $61 \%$ of cases with unsuccessful drought adaptation. The analysis of sufficiency results in a solution with high consistency (1) but rather low explanatory power $(0.389)$. The solution includes three paths, none of which is common to the Asian or American archetype WUAs. Asian WUAs feature a path to unsuccessful adaptation that includes the absence of transfer inflows, the absence of participation, and the presence of strengthened monitoring. This path is fully consistent and explains $20 \%$ of cases with unsuccessful adaptation. The other two paths are contingent on the American archetype. Both paths are fully consistent and explain close to $40 \%$ of the unsuccessful adaptation cases. Both of them include strong participation; one also includes the absence of transfer inflows, and the other includes the presence of strengthened monitoring.

According to interviews, the massive attendance of farmers at meetings (participation) and the need for guards to reinforce supervision (monitoring) are symptoms of, rather than solutions to, water management issues. As one interviewee noted, "If everything goes as expected, nobody comes to the meetings." Meetings in the advent of droughts and other disturbances are usually used by farmers to complain about the lack of water and demand solutions from the executive committee. Although the information shared in the meetings during droughts can be important, there are other mechanisms through which farmers can get information, including communicating directly with the secretary, guard, or any member of the executive board or looking at the public announcements made by the WUA. Similarly, the water allocation system facilitates monitoring because water is allocated in turns from the start to the end of canals (one neighbor after the other) directly by the guard or metered. Thus, as hinted by interviewees, intensification of patrolling (in most WUAs) or hiring a new guard (in a few Asian WUAs) occurs when the executive board expects misbehavior.

Overall, all paths associated with unsuccessful adaptation involve the lack of inflow transfers and/or strong participation and/or the presence of strengthened monitoring. The findings, however, have to be taken with caution because they explain less than half of the poor drought performance cases.

\section{DISCUSSION}

\section{Archetypes of irrigation management and paths of drought adaptation: prevalence of the Asian and American type distinction}

The Asian vs. American archetypes theory resonates with a good number of works on irrigation management (Tang 1991, Trawick 2001, Meinzen-Dick et al. 2002, Palerm Viqueira 2002), but has rarely been mobilized explicitly. Here, we operationalized the distinction by looking at biophysical, technical, sociopolitical, and institutional conditions.

We found alignments between the age of the systems, sizes of systems and farm plots, aging of farmers, political heterogeneity of the systems, and presence of guard monitoring, all of which validate the Asian vs. American archetypes distinction. However, we also found it important to distinguish the traditional Asian from the modernized Asian, and the old American from the new American archetypes given the history of technological improvements in the area of study. Investments in infrastructure maintenance and improvements are inherent to irrigation management (Levine 1977, Ostrom 1992). Since the 2000s, a new wave of such investments has been promoted in many countries, triggered by concerns around water productivity, rural-urban competition over fresh water resources, and, more recently, climate change (Turral et al. 2010). A focus on transitioning 
Table 3. Configurations of conditions that are sufficient for successful and unsuccessful drought adaptation. We ran the qualitative comparative analysis including the cluster dummy variable and the three adaptation institutions (transfers, monitoring, and participation). To emphasize the existence of distinct paths depending on the archetype, we display this condition in a separate column. Thus, the first solution of the Asian archetype row was CLUSTER $\times$ TRANSFERS $\times$ MONITORING, and the first solution of the American model row was cluster $\times$ TRANSFERS $\times$ participation. Conditions in all-capitals are present in the solution, whereas conditions in lowercase are absent. Conditions that do not appear in the solution are either present or absent.

\begin{tabular}{|c|c|c|}
\hline Archetype & $\begin{array}{l}\text { Successful drought adaptation } \\
\text { (intermediate/parsimonious solution) } \\
\text { Consistency }=0.923 \text {, coverage }=0.632\end{array}$ & $\begin{array}{l}\text { Unsuccessful drought adaptation } \\
\text { (intermediate solution) } \\
\text { Consistency }=0.1 \text {, coverage }=0.389\end{array}$ \\
\hline Archetype independent & $\begin{array}{l}\text { (1) TRANSFERS } \times \text { participation } \times \text { MONITORING } \\
(1,0.212, N=4)^{\ddagger}\end{array}$ & N/A \\
\hline $\begin{array}{l}\text { Asian } \\
\text { (traditional and } \\
\text { modernized) }\end{array}$ & $\begin{array}{l}(1) \text { TRANSFERS } \times \text { MONITORING } \\
(1,0.182, N=2) \\
(2) \text { transfers } \times \text { participation } \times \text { monitoring } \\
(1,0.28, N=3)\end{array}$ & $\begin{array}{l}(1) \text { transfers } \times \text { participation } \times \text { MONITORING } \\
(1,0.2, N=2)\end{array}$ \\
\hline $\begin{array}{l}\text { American } \\
\text { (old and new) }\end{array}$ & $\begin{array}{l}\text { (1) TRANSFERS } \times \text { participation } \\
(0.86,0.75, N=6) \\
(2) \text { TRANSFERS } \times \text { monitoring } \\
(0.8,0.5, N=4)\end{array}$ & $\begin{array}{l}\text { (1) transfers } \times \text { PARTICIPATION } \\
(1,0.375, N=3) \\
(2) \text { PARTICIPATION } \times \text { MONITORING } \\
(1,0.375, N=3)\end{array}$ \\
\hline
\end{tabular}

archetypes such as the modernized Asian WUAs in the assessment of irrigation management can be particularly enlightening with regard to the opportunities and challenges of said infrastructure improvement efforts.

Also, our data show that Asian-like WUAs would be more likely to engage in infrastructure improvements than American-like WUAs (see, in particular, modernized Asian vs. old American WUAs). This finding qualifies associations previously made about the ability of traditional irrigation systems to deal with technological innovations (Burt 2013). Importantly though, farmers from the RAA project who invested in "modernization" were not necessarily or uniquely interested in increasing water productivity or conserving water, but rather aimed at reducing the time and effort devoted to certain agricultural activities such as watering the fields, or at increasing the value of their land. Thus, as noted in previous studies, one should not automatically associate said investments with drought resilience, or even with water management (Prager and Posthumus 2010). Also importantly, the modernized Asian WUAs had to go through a quite unique process of social and institutional learning first to adopt and then to integrate the new technology in their management systems. This characteristic makes it quite different from new American WUAs, which were created with such technology from the start. Here again, understanding each cluster in its historical perspective reveals particularly important information.

According to our results, different archetypes of irrigation systems profile different paths to drought adaptation, and each have their own idiosyncrasies. For example, the two Asian paths are quite different from each other. This is an asset because diversity of adaptation alternatives can ameliorate trade-offs between adapting to some disturbances over others (Low et al. 2002, Janssen and Anderies 2007). Such diversity is additionally illustrated by the relatively low coverage of the two paths, i.e., 6 of the 11 Asian successful drought adaptation cases profile other paths to adaptation. Alternatively, the American paths are relatively similar to each other in their reliance on transfer inflows. Here, the dependence of American WUAs on transfer inflows can be associated with their relatively strong reliance on summer crops and would be revealing a potential source of vulnerability in the absence of those transfers or changes in the rules that govern them. Such vulnerability is not deniable given the high coverage of the paths. Contrary to the Asian paths, the American paths cover all cases of successful drought adaptation associated with the archetype (i.e., there are no other paths to successful adaptation among American WUAs).

A look at cropping patterns is revealing regarding the reliance of American WUAs on transfers. The average proportion of area devoted to summer crops (high water demand crops) was quite similar in the successfully adapted Asian WUAs and in the successfully adapted American WUAs during the drought $(50 \%$ vs. $57 \%$, respectively); however, that was not the case during the previous, nondrought year (i.e., 2004), when there was a difference of 14 points between both archetypes ( $66 \%$ vs. $80 \%$, respectively). In other words, from 2004 to 2005, the performing Asian WUAs decreased their coverage of summer crops by an average of $16 \%$ and the performing American WUAs did so by $23 \%$. This shows that the cooperation effort made by farmers in the latter case was visibly higher than in the former. When looking at unsuccessfully adapted WUAs, however, the difference disappears (18\% vs. 19\% change, respectively).

Also important is participation, which plays a role in the two American paths to unsuccessful drought adaptation. This highlights the importance of collective choice venues as a means to raise awareness about performance issues, at least in the American WUAs. In large, relatively heterogeneous systems like the American systems, institutionalized collective choice arenas tend to be the main means for communication and deliberation 
among all farmers (Meinzen-Dick et al. 1994). This is not necessarily the case in smaller, more homogeneous systems like the Asian systems, where informal communication channels can be sufficient (Palerm Viqueira 2000).

Finally, despite the discriminating role played by technology (i.e., modernization) in the HCA, we did not find a clear alignment between the use of modern infrastructure (new American and modernized Asian WUAs) and successful drought adaptation. This result shows two things. First, the distinction between modernized and nonmodernized systems to promote infrastructure improvement investments (Burt 2013) looks rather simplistic when assessed with regard to other social-ecological conditions. Second, although sprinkler irrigation has higher efficiency than flood irrigation, paths to drought robustness should not be univocally associated with the former.

\section{Generic and specific adaptation institutions: Are they always relevant?}

Our results also suggest that the distinction between generic and specific adaptation capacity is useful to theorize about different ways to institutionalize adaptation. We next discuss the role played by the three adaptation institutions in the study (transfer inflows, collective choice participation, and strengthened monitoring).

The possibility to transfer water across systems if requested by a farmer with land in both systems is one of the most paradigmatic institutions specifically designed to cope with droughts in the RAA project. The institution is indeed present in four of the five paths to successful drought adaptation. As informed by the interviewees, the reliance on transfer inflows may be driven by different reasons. Farmers with land in systems that use sprinkler irrigation tend to concentrate their water use rights in those systems because of the higher water productivity. This would be congruent with a good number of the American systems (mostly the new American WUAs). Alternatively, the reliance on transfer inflows in WUAs without sprinkler irrigation (traditional Asian WUAs) is likely justified by the willingness of farmers to concentrate their production nearby agricultural cooperatives or in systems where they also cultivate rainfed crops to reduce their travel times.

Our results also show that the transfer institution works well regardless of the absence of one or both of the two generic adaptation institutions. In most of the successful drought adaptation cases that rely on the transfers institution (in particular, American WUAs), the effectiveness of said institution coincides with either the absence of participation or the absence of strengthened monitoring. This result is understandable when looking at the process of water management during droughts. The transfer institution (as well as the quota policy upon which it relies) has been in place for many years, and the decision to use it during an irrigation campaign is contingent on the activation of the drought protocol at the RAA project level. There is, therefore, no need to make any additional decision at the WUA level other than to inform farmers about the situation so they can plan their cropping accordingly. This helps to understand why the transfers institution works in the absence of participation. Also, there is a general understanding among farmers in many WUAs that rule violations are particularly damaging for the performance of the quota policy (Villamayor-Tomas 2014b). This helps to understand why the transfer institution works in the absence of strengthened monitoring for many cases.

Collective choice participation and monitoring institutions have been associated frequently with the robustness of CBNRM systems (Agrawal 2001). It is unclear, however, how they are relevant and under which conditions (Anderies et al. 2004). According to our results, these institutions are not particularly important during droughts. Participation was absent in all successful paths to successful drought adaptation, and monitoring was absent in two of the paths. They are important as symptoms of performance issues that WUA leaders need to address, but their contribution to solving those issues during droughts seems rather limited. In the paths to successful adaptation, monitoring always comes with the presence of transfers. This result is intuitive, considering that the transfer institution makes the accounting of water use and quotas more complex than otherwise. In the paths to unsuccessful adaptation, however, monitoring is also present, even when transfers are absent. This result suggests that strengthened monitoring can be also interpreted as a symptom of adaptation issues. As noted by interviewees, the strengthening of monitoring would respond more to the goal of dissuading misbehavior at large in systems where WUAs have already suffered from it; however, the dissuasive power of monitoring decreases if it is not communicated or assimilated well in advance by resource users, particularly if their livelihoods are at stake (Coleman and Steed 2009).

Similarly, during droughts and other periods of stress, stakes are high, distributional implications of solutions are particularly salient, and collective decisions (i.e., participation) tend to be controversial. This situation has been quite clear in the minds of the WUA and GCRAA leaders every time they have had the need to reform the drought protocol (e.g., the quota and the transfers institution). As noted by one of those leaders, users want to know what to expect during droughts; they need a clear drought protocol, not to engage in discussions with uncertain results. The best moment to introduce reforms is in the aftermath of droughts, when farmers are still sensitive and motivated to change and less concerned or attentive to who gets what and the overall fairness of solutions. Indeed, the vividness of experiences and the veil of ignorance associated with low stakes have been pointed out to be quite crucial factors of organizational change (Fernandez and Rainey 2006).

\section{CONCLUSIONS}

We aimed to add to the knowledge about the conditions that explain adaptation in CBRNM systems, particularly selfgoverned irrigation systems. For that purpose, we used an archetype analysis approach, according to which theory building and testing requires contextualized generalizations.

The comparison of paths to successful and unsuccessful adaptation revealed insights about whether and how CBNRM adapts to disturbances. According to our findings, WUAs adapt to droughts by relying on different combinations of generic adaptation institutions (i.e., generally contributing to adaptation) and specific adaptation institutions (i.e., tailored to cope with particular disturbances such as droughts). The water transfer institution (specific) showed particular relevance during droughts, whereas the participation in assembly meetings and 
strengthened monitoring (generic) played roles both during droughts (monitoring to support the implementation of the transfer institution in some WUAs), as well as in the aftermath of droughts (e.g., assembly meetings to decide how to cope with future droughts). Further research shall explore other specifications of generic institutions such as self-financing rules, cross-scale linkages, or disaster relief programs, as well as other drought-specific institutions such as crop control or property right buyouts. Similarly, further research shall test the relevance of generic and specific institutions with respect to other important disturbances such as crop and input price crises or plagues (Villamayor-Tomas and García-López 2017).

Also importantly, the distinction between the American and Asian types of irrigation system can be useful to study adaptation but requires reinterpretation with regard to the specific contexts and history of the cases under study. In the RAA project, technological aspects and the recent history of modernization investments (piped canals and sprinkler irrigation) played a key role to distinguish different versions of the American and Asian archetypes (traditional vs. modernized Asian WUAs, and new vs. old American WUAs). Also, paths leading to successful drought adaptation aligned with the American vs. Asian distinction. The Asian paths to drought adaptation were more diverse (i.e., different among themselves) than the American paths, which makes the former potentially less vulnerable to institutional failure or regime changes than the latter. Additionally, we did not find an alignment between modernization or the use of newer infrastructure or technology and drought adaptation, which questions the massive infrastructure investments made in response to droughts in the last decades both in Spain and globally (López-Gunn et al. 2013).

From a methodological point of view, the combination of the "archetypes as typologies of cases" and the "archetypes as building blocks" approaches was useful to move archetype analysis forward. The lack of clear guidelines to feature the contexts to which theories apply is a key challenge in archetype analysis (Eisenack et al. 2019). The identification of archetypes of irrigation systems through HCA allowed us to meaningfully synthesize a relatively large number of irrigation system conditions. The Asian vs. American ideal type distinction theory helped in that process. The archetypes of irrigation systems were in turn used as inputs in the QCA. This procedure proved to be quite practical, given that QCA (and the building blocks approach more generally) is not particularly effective with large numbers of conditions. Future archetype analysis research shall explore the usefulness of more grounded theory-based approaches to context characterization as well as the combination of HCA analysis with regression techniques.

Responses to this article can be read online at: http://www.ecologyandsociety.org/issues/responses. php/11329

\section{Acknowledgments:}

Sergio Villamayor-Tomas and Irene Iniesta-Arandia acknowledge financial support from the Spanish Ministry of Sciences, Innovation and Universities, through the "Ramon y Cajal" program (grant RYC-2017-22782) and the "Juan de la Cierva-Incorporación" program (grant IJCI-2017-33405), respectively; and the "Maria de Maeztu” program for Units of Excellence (MDM-2015-0552). Sergio Villamayor-Tomas also thanks financial support from the National Science Foundation Dissertation Improvement Grant Program (award 1120122) and from the Vincent and Elinor Ostrom Workshop in Political Theory and Policy Analysis.

\section{LITERATURE CITED}

Acemoglu, D., S. Johnson, and J. Robinson. 2005. The rise of Europe: Atlantic trade, institutional change, and economic growth. American Economic Review 95(3):546-579. https://doi. org/10.1257/0002828054201305

Adger, W. N. 2003. Social capital, collective action, and adaptation to climate change. Economic Geography 79 (4):387-404. https://doi.org/10.1111/j.1944-8287.2003.tb00220.x

Adger, W. N. 2006. Vulnerability. Global Environmental Change 16(3):268-281. https://doi.org/10.1016/j.gloenvcha.2006.02.006

Agrawal, A. 2001. Common property institutions and sustainable governance of resources. World Development 29(10):1649-1672. https://doi.org/10.1016/S0305-750X(01)00063-8

Anderies, J. M., M. Janssen, and E. Ostrom. 2004. A framework to analyze the robustness of social-ecological systems from an institutional perspective. Ecology and Society 9(1):18. [online] URL: http://www.ecologyandsociety.org/vol9/iss1/art18/

Arriaza, M., J. A. Gómez-Limón, and M. Upton. 2002. Local water markets for irrigation in southern Spain: a multicriteria approach. Australian Journal of Agricultural and Resource Economics 46(1):21-43. https://doi.org/10.1111/1467-8489.00165

Baggio, J. A., A. J. Barnett, I. Perez-Ibarra, U. Brady, E. Ratajczyk, N. Rollins, C. Rubiños, H. C. Shin, D. J. Yu, R. Aggarwal, J. M. Anderies, and M. A. Janssen. 2016. Explaining success and failure in the commons: the configural nature of Ostrom's institutional design principles. International Journal of the Commons 10(2):417-439. https://doi.org/10.18352/ijc.634

Baird, J., R. Plummer, C. Haug, and D. Huitema. 2014. Learning effects of interactive decision-making processes for climate change adaptation. Global Environmental Change 27:51-63. https://doi.org/10.1016/j.gloenvcha.2014.04.019

Biesbroek, G. R., C. J. A. M. Termeer, J. E. M. Klostermann, and P. Kabat. 2014. Rethinking barriers to adaptation: mechanismbased explanation of impasses in the governance of an innovative adaptation measure. Global Environmental Change 26:108-118. https://doi.org/10.1016/j.gloenvcha.2014.04.004

Bisaro, A., and J. Hinkel. 2016. Governance of social dilemmas in climate change adaptation. Nature Climate Change 6 (4):354-359. https://doi.org/10.1038/nclimate2936

Boken, V. K., A. P. Cracknell, and R. L. Heathcote, editors. 2005. Monitoring and predicting agricultural drought: a global study. Oxford University Press, Oxford, UK.

Bray, J. R., and J. T. Curtis. 1957. An ordination of the upland forest communities of southern Wisconsin. Ecological Monographs 27(4):325-349. https://doi.org/10.2307/1942268 
Buchanan, J., D. H. Chai, and S. Deakin. 2014. Empirical analysis of legal institutions and institutional change: multiple-methods approaches and their application to corporate governance research. Journal of Institutional Economics 10(1):1-20. https:// doi.org/10.1017/S1744137413000349

Burt, C. M. 2013. The irrigation sector shift from construction to modernization: What is required for success? Irrigation and Drainage 62(3):247-254. https://doi.org/10.1002/ird.1703

Carpenter, S., B. Walker, J. M. Anderies, and N. Abel. 2001. From metaphor to measurement: Resilience of what to what? Ecosystems 4(8):765-781. https://doi.org/10.1007/s10021-001-0045-9

Cazcarro, I., R. Duarte, and J. Sánchez-Chóliz. 2013. Economic growth and the evolution of water consumption in Spain: a structural decomposition analysis. Ecological Economics 96:51-61. https://doi.org/10.1016/j.ecolecon.2013.09.010

Chong, H., and D. Sunding. 2006. Water markets and trading. Annual Review of Environment and Resources 31:239-264. https:// doi.org/10.1146/annurev.energy.31.020105.100323

Coleman, E. A., and B. C. Steed. 2009. Monitoring and sanctioning in the commons: an application to forestry. Ecological Economics 68(7):2106-2113. https://doi.org/10.1016/j. ecolecon.2009.02.006

Cox, M., G. Arnold, and S. Villamayor-Tomás. 2010. A review of design principles for community-based natural resource management. Ecology and Society 15(4):38. https://doi. org/10.5751/ES-03704-150438

Cox, M., S. Villamayor-Tomas, G. Epstein, L. Evans, N. C. Ban, F. Fleischman, M. Nenadovic, and G. Garcia-Lopez. 2016. Synthesizing theories of natural resource management and governance. Global Environmental Change 39:45-56. https://doi. org/10.1016/j.gloenvcha.2016.04.011

Cox, M., S. Villamayor-Tomas, and Y. Hartberg. 2014. The role of religion in community-based natural resource management. World Development 54:46-55. https://doi.org/10.1016/j. worlddev.2013.07.010

Cundill, G. 2010. Monitoring social learning processes in adaptive comanagement: three case studies from South Africa. Ecology and Society 15(3):28. https://doi.org/10.5751/ES-03467-150328

Eakin, H. 2005. Institutional change, climate risk, and rural vulnerability: cases from central Mexico. World Development 33 (11):1923-1938. https://doi.org/10.1016/j.worlddev.2005.06.005

Eakin, H. C., M. C. Lemos, and D. R. Nelson. 2014. Differentiating capacities as a means to sustainable climate change adaptation. Global Environmental Change 27:1-8. https:// doi.org/10.1016/j.gloenvcha.2014.04.013

Eisenack, K., and R. Stecker. 2012. A framework for analyzing climate change adaptations as actions. Mitigation and Adaptation Strategies for Global Change 17:243-260. https://doi.org/10.1007/ $\underline{\text { s11027-011-9323-9 }}$

Eisenack, K., S. Villamayor-Tomas, G. Epstein, C. Kimmich, N. Magliocca, D. Manuel-Navarrete, C. Oberlack, M. Roggero, and D. Sietz. 2019. Design and quality criteria for archetype analysis. Ecology and Society 24(3):6. https://doi.org/10.5751/ES-10855-240306
Fernandez, S., and H. G. Rainey. 2006. Managing successful organizational change in the public sector. Public Administration Review 66(2):168-176. https://doi.org/10.1111/j.1540-6210.2006.00570. $\underline{\mathrm{x}}$

Füssel, H.-M., and R. J. T. Klein. 2006. Climate change vulnerability assessments: an evolution of conceptual thinking. Climatic Change 75(3):301-329. https://doi.org/10.1007/s10584-006-0329-3

Garces-Restrepo, C., D. Vermillion, and G. Muñoz. 2007. Irrigation management transfer: worldwide efforts and results. FAO Water Reports 32. Food and Agriculture Organization, Rome, Italy. [online] URL: http://www.fao.org/nr/wman/abst/wman_080401_en. $\underline{\mathrm{htm}}$

Gil Sevilla, M., A. Garrido Colmenero, and N. Hernández-Mora Zapata. 2013. Direct and indirect economic impacts of drought in the agri-food sector in the Ebro River basin (Spain). Natural Hazards and Earth System Sciences 13(10):2679-2694. https://doi. org/10.5194/nhess-13-2679-2013

Glick, T. F. 1970. Irrigation and society in medieval Valencia. Harvard University Press, Cambridge, Massachusetts, USA. https://doi.org/10.4159/harvard.9780674281806

Gómez-Baggethun, E., V. Reyes-García, P. Olsson, and C. Montes. 2012. Traditional ecological knowledge and community resilience to environmental extremes: a case study in Doñana, SW Spain. Global Environmental Change 22(3):640-650. https://doi. org/10.1016/j.gloenvcha.2012.02.005

Grothmann, T., and A. Patt. 2005. Adaptive capacity and human cognition: the process of individual adaptation to climate change. Global Environmental Change 15(3):199-213. https://doi. org/10.1016/j.gloenvcha.2005.01.002

Hinkel, J., and A. Bisaro. 2015. A review and classification of analytical methods for climate change adaptation. Wiley Interdisciplinary Reviews: Climate Change 6(2):171-188. https:// doi.org/10.1002/wcc.322

Hodgson, G. M. 1998. The approach of institutional economics. Journal of Economic Literature 36(1):166-192. [online] URL: https://www.jstor.org/stable/2564954

Huntjens, P., L. Lebel, C. Pahl-Wostl, J. Camkin, R. Schulze, and N. Kranz. 2012. Institutional design propositions for the governance of adaptation to climate change in the water sector. Global Environmental Change 22(1):67-81. https://doi.org/10.1016/ j.gloenvcha.2011.09.015

Iniesta-Arandia, I., M. García-Llorente, P. A. Aguilera, C. Montes, and B. Martín-López. 2014. Socio-cultural valuation of ecosystem services: uncovering the links between values, drivers of change, and human well-being. Ecological Economics 108:36-48. https://doi.org/10.1016/j.ecolecon.2014.09.028

Janssen, M. A., and J. M. Anderies. 2007. Robustness trade-offs in social-ecological systems. International Jounal of the Commons 1(1):43-66. https://doi.org/10.18352/ijc. 12

Lam, W. F. 2006. Foundations of a robust social-ecological system: irrigation institutions in Taiwan. Journal of Institutional Economics 2(2):203-226. https://doi.org/10.1017/S1744137406000348

Lam, W. F., and E. Ostrom. 2010. Analyzing the dynamic complexity of development interventions: lessons from an 
irrigation experiment in Nepal. Policy Sciences 43:1-25. https:// doi.org/10.1007/s11077-009-9082-6

Lecina, S., D. Isidoro, E. Playán, and R. Aragüés. 2010. Irrigation modernization and water conservation in Spain: the case of Riegos del Alto Aragón. Agricultural Water Management 97 (10):1663-1675. https://doi.org/10.1016/j.agwat.2010.05.023

Lemos, M. C., A. Agrawal, H. Eakin, D. R. Nelson, N. L. Engle, and O. Johns. 2013. Building adaptive capacity to climate change in less developed countries. Pages 437-457 in G. R. Asrar and J. W. Hurrell, editors. Climate science for serving society: research, modeling and prediction priorities. Springer, Dordrecht, The Netherlands. https://doi.org/10.1007/978-94-007-6692-1 16

Levine, G. 1977. Management components in irrigation system design and operation. Agricultural Administration 4(1):37-48. https://doi.org/10.1016/0309-586X(77)90031-0

López Gálvez, J., and J. M. Naredo. 1997. La gestión del agua de riego. Fundación Argentaria, Madrid, Spain.

López-Gunn, E., B. Mayor, and A. Dumont. 2013. Implications of the modernization of irrigation systems. Pages 241-258 in L. De Stefano and M. R. Llamas, editors. Water, agriculture and the environment in Spain: Can we square the circle? CRC Press, Boca Raton, Florida, USA.

López-Moreno, J. I., S. M. Vicente-Serrano, M. AnguloMartínez, S. Beguería, and A. Kenawy. 2010. Trends in daily precipitation on the northeastern Iberian Peninsula, 1955-2006. International Journal of Climatology 30(7):1026-1041. https://doi. org/10.1002/joc. 1945

Low, B., E. Ostrom, C. Simon, and J. Wilson. 2002. Redundancy and diversity: do they influence optimal management? Pages 83-114 in F. Berkes, J. Colding, and C. Folke, editors. Navigating social-ecological systems: building resilience for complexity and change. Cambridge University Press, Cambridge, UK. https://doi. org/10.1017/CBO9780511541957.007

Martín-López, B., I. Palomo, M. García-Llorente, I. IniestaArandia, A. J. Castro, D. García Del Amo, E. Gómez-Baggethun, and C. Montes. 2017. Delineating boundaries of social-ecological systems for landscape planning: a comprehensive spatial approach. Land Use Policy 66:90-104. https://doi.org/10.1016/j. landusepol.2017.04.040

McCord, P. F., M. Cox, M. Schmitt-Harsh, and T. Evans. 2015. Crop diversification as a smallholder livelihood strategy within semi-arid agricultural systems near Mount Kenya. Land Use Policy 42:738-750. https://doi.org/10.1016/j.landusepol.2014.10.012

Medzihorsky, J., I. E. Oana, M. Quaranta, and C. Q. Schneider. 2016. SetMethods: functions for set-theoretic multi-method research and advanced $Q C A$. R package version 2 .

Meinzen-Dick, R. 2007. Beyond panaceas in water institutions. Proceedings of the National Academy of Sciences 104 (39):15200-15205. https://doi.org/10.1073/pnas.0702296104

Meinzen-Dick, R., M. Mendoza, L. Sadoulet, G. Abiad-Shields, and A. Subramanian. 1994. Sustainable water user associations: lessons from a literature review. Agriculture and Natural Resource Department, World Bank, Washington, D.C., USA.
Meinzen-Dick, R., K. V. Raju, and A. Gulati. 2002. What affects organization and collective action for managing resources? Evidence from canal irrigation systems in India. World Development 30(4):649-666. https://doi.org/10.1016/S0305-750X (01)00130-9

Murtinho, F., and T. M. Hayes. 2012. Adaptation in resourcedependent communities: a call for greater methodological clarity in adaptation field research. Society and Natural Resources 25 (5):513-522. https://doi.org/10.1080/08941920.2011.604068

Nguyen, T. P. L., G. Seddaiu, S. G. P. Virdis, C. Tidore, M. Pasqui, and P. P. Roggero. 2016. Perceiving to learn or learning to perceive? Understanding farmers' perceptions and adaptation to climate uncertainties. Agricultural Systems 143:205-216. https://doi. org/10.1016/j.agsy.2016.01.001

O'Brien, K., B. Hayward, and F. Berkes. 2009. Rethinking social contracts: building resilience in a changing climate. Ecology and Society 14(2):12. https://doi.org/10.5751/ES-03027-140212

Oberlack, C., and K. Eisenack. 2018. Archetypical barriers to adapting water governance in river basins to climate change. Journal of Institutional Economics 14(3):527-555. https://doi. org/10.1017/S1744137417000509

Oberlack, C., D. Sietz, E. Bürgi Bonanomi, A. de Bremond, J. Dell'Angelo, K. Eisenack, E. C. Ellis, G. Epstein, M. Giger, A. Heinimann, C. Kimmich, M. T. J. Kok, D. Manuel-Navarrete, P. Messerli, P. Meyfroidt, T. Václavík, and S. Villamayor-Tomas. 2019. Archetype analysis in sustainability research: meanings, motivations, and evidence-based policy making. Ecology and Society 24(2):26. https://doi.org/10.5751/ES-10747-240226

Oberlack, C., L. Tejada, P. Messerli, S. Rist, and M. Giger. 2016. Sustainable livelihoods in the global land rush? Archetypes of livelihood vulnerability and sustainability potentials. Global Environmental Change 41:153-171. https://doi.org/10.1016/j. gloenvcha.2016.10.001

Ostrom, E. 1990. Governing the commons: the evolution of institutions for collective action. Cambridge University Press, Cambridge, UK.

Ostrom, E. 1992. Crafting institutions for self-governing irrigation systems. ICS Press, San Francisco, California, USA.

Ostrom, E. 2007. A diagnostic approach for going beyond panaceas. Proceedings of the National Academy of Sciences 104 (39):15181-15187. https://doi.org/10.1073/pnas.0702288104

Pahl-Wostl, C., E. Mostert, and D. Tàbara. 2008. The growing importance of social learning in water resources management and sustainability science. Ecology and Society 13(1):24. https://doi. org/10.5751/ES-02352-130124

Palerm Viqueira, J. 2000. Organización social y agricultura de riego. In J. Palerm Viqueira and T. Martínez Saldaña, editors. Antología sobre pequeño riego: organizaciones autogestivas. Plaza y Valdés, Mexico City, Mexico.

Palerm Viqueira, J. 2002. Governance and organizational type for the administration of irrigation systems. In International e-mail conference on irrigation management transfer, June-October 2001. FAO Land and Water Digital Media Series 17. Food and Agriculture Organization, Rome, Italy. 
Palerm Viqueira, J. 2008. Distritos de riego en México, algunos mitos. Boletín del Archivo Histórico del Agua 38:50-70. [online] URL: $\underline{\text { https://dialnet.unirioja.es/servlet/articulo?codigo }=3187729}$

Pelling, M., and C. High. 2005. Understanding adaptation: What can social capital offer assessments of adaptive capacity? Global Environmental Change 15(4):308-319. https://doi.org/10.1016/j. gloenvcha.2005.02.001

Poteete, A. R., M. A. Janssen, and E. Ostrom. 2010. Working together. Princeton University Press, Princeton, New Jersey, USA. https://doi.org/10.1515/9781400835157

Prager, K., and H. Posthumus. 2010. Socio-economic factors influencing farmers' adoption of soil conservation practices in Europe. Pages 203-223 in T. L. Napier, editor. Human dimensions of soil and water conservation: a global perspective. Nova Science Publishers, Hauppauge, New York, USA.

Pujol, J., M. Raggi, and D. Viaggi. 2006. The potential impact of markets for irrigation water in Italy and Spain: a comparison of two study areas. Australian Journal of Agricultural and Resource Economics 50(3):361-380. https://doi.org/10.1111/j.1467-8489.2006.00352. $\underline{\mathrm{x}}$

Ragin, C. 2000. Fuzzy-set social science. University of Chicago Press, Chigaco, Illinois, USA.

Ragin, C. C. 2005. Core versus tangential assumptions in comparative research. Studies in Comparative International Development 40:33-38. https://doi.org/10.1007/BF02686286

Rihoux, B., and C. C. Ragin. 2009. Configurational comparative methods: qualitative comparative analysis (QCA) and related techniques. Sage, Thousand Oaks, California, USA.

Roggero, M., A. Bisaro, and S. Villamayor-Tomas. $2018 a$. Institutions in the climate adaptation literature: a systematic literature review through the lens of the Institutional Analysis and Development framework. Journal of Institutional Economics 14(3):423-448. https://doi.org/10.1017/S1744137417000376

Roggero, M., S. Villamayor-Tomas, C. Oberlack, K. Eisenack, A. Bisaro, J. Hinkel, and A. Thiel. 2018b. Introduction to the special issue on adapting institutions to climate change. Journal of Institutional Economics 14(3):409-422. https://doi.org/10.1017/ $\underline{\text { S1744137417000649 }}$

Salvador, R., A. Martínez-Cob, J. Cavero, and E. Playán. 2011. Seasonal on-farm irrigation performance in the Ebro basin (Spain): crops and irrigation systems. Agricultural Water Management 98(4):577-587. https://doi.org/10.1016/j.agwat.2010.10.003

Schneider, C. Q., and C. Wagemann. 2006. Reducing complexity in Qualitative Comparative Analysis (QCA): remote and proximate factors and the consolidation of democracy. European Journal of Political Research 45(5):751-786. https://doi. org/10.1111/j.1475-6765.2006.00635.x

Schneider, C. Q., and C. Wagemann. 2010. Standards of good practice in qualitative comparative analysis (QCA) and fuzzy-sets. Comparative Sociology 9(3):397-418. https://doi. org/10.1163/156913210X12493538729793

Seara, T., P. M. Clay, and L. L. Colburn. 2016. Perceived adaptive capacity and natural disasters: a fisheries case study. Global
Environmental Change 38:49-57. https://doi.org/10.1016/j. gloenvcha.2016.01.006

Sietz, D., U. Frey, M. Roggero, Y. Gong, N. Magliocca, R. Tan, P. Janssen, and T. Václavík. 2019. Archetype analysis in sustainability research: methodological portfolio and analytical frontiers. Ecology and Society 24(3):34. https://doi.org/10.5751/ ES-11103-240334

Sietz, D., J. C. Ordoñez, M. T. J. Kok, P. Janssen, H. B. M. Hilderink, P. Tittonell, and H. Van Dijk. 2017. Nested archetypes of vulnerability in African drylands: Where lies potential for sustainable agricultural intensification? Environmental Research Letters 12(9):095006. https://doi.org/10.1088/1748-9326/aa768b

Smit, B., I. Burton, R. J. T. Klein, and J. Wandel. 2000. An anatomy of adaptation to climate change and variability. Climatic Change 45:223-251. https://doi.org/10.1023/A:1005661622966

Smit, B., and J. Wandel. 2006. Adaptation, adaptive capacity and vulnerability. Global Environmental Change 16(3):282-292. https://doi.org/10.1016/j.gloenvcha.2006.03.008

Stern, P. C., T. Dietz, N. Dolsak, E. Ostrom, and S. Stonich. 2002. Knowledge and questions after 15 years of research. Pages 445-490 in E. Ostrom, T. Dietz, N. Dolsak, P. C. Stern, S. Stonich, and E. U. Weber, editors. The drama of the commons. National Academy Press, Washington, D.C., USA.

Streeck, W., and K. Thelen. 2005. Introduction: institutional change in advanced political economies. Pages 3-39 in W. Streeck and $\mathrm{K}$. Thelen, editors. Beyond continuity: institutional change in advanced political economies. Oxford University Press, Oxford, UK.

Tang, S. Y. 1991. Institutional arrangements and the management of common-pool resources. Public Administration Review 51 (1):42-51. https://doi.org/10.2307/976635

Tang, S. Y. 1992. Institutions and collective action: self-governance in irrigation. ICS Press, San Francisco, California, USA.

Thiem, A., and A. Dusa. 2013. Qualitative comparative analysis with R: a user's guide. Springer, New York, New York, USA.

Tompkins, E. L., and W. N. Adger. 2004. Does adaptive management of natural resources enhance resilience to climate change? Ecology and Society 9(2):10. [online] URL: http://www. ecologyandsociety.org/vo19/iss2/art10/

Trawick, P. B. 2001. Successfully governing the commons: principles of social organization in an Andean irrigation system. Human Ecology 29:1-25. https://doi.org/10.1023/A:1007199304395

Trawick, P. 2003. Against the privatization of water: an indigenous model for improving existing laws and successfully governing the commons. World Development 31(6):977-996. https://doi.org/10.1016/S0305-750X(03)00049-4

Turral, H., M. Svendsen, and J. M. Faures. 2010. Investing in irrigation: reviewing the past and looking to the future. Agricultural Water Management 97(4):551-560. https://doi. org/10.1016/j.agwat.2009.07.012

Václavík, T., S. Lautenbach, T. Kuemmerle, and R. Seppelt. 2013. Mapping global land system archetypes. Global Environmental Change 23(6):1637-1647. https://doi.org/10.1016/j.gloenvcha.2013.09.004 
Vicente-Serrano, S. M. 2004. Evaluación de las consecuencias ambientales de las sequías en el sector central del valle del ebro mediante imágenes de satélite: posibles estrategias de mitigación. Consejo Económico y Social de Aragón, Zaragoza, Spain. [online] URL: https://www.aragon.es/documents/20127/674325/ TESIS BAJA_2004.pdf/d1a0ddd9-5af1-788a-bfe1-68e00d679d14

Vicente-Serrano, S. M., S. Beguería, and J. I. López-Moreno. 2010. A multiscalar drought index sensitive to global warming: the standardized precipitation evapotranspiration index. Journal of Climate 23(7):1696-1718. https://doi.org/10.1175/2009JCLI2909.1

Vicente-Serrano, S. M., and J. M. Cuadrat-Prats. 2007. Trends in drought intensity and variability in the middle Ebro valley (NE of the Iberian peninsula) during the second half of the twentieth century. Theoretical and Applied Climatology 88:247-258. https:// doi.org/10.1007/s00704-006-0236-6

Villamayor-Tomas, S. 2014a. Cooperation in common property regimes under extreme drought conditions: empirical evidence from the use of pooled transferable quotas in Spanish irrigation systems. Ecological Economics 107:482-493. https://doi. org/10.1016/j.ecolecon.2014.09.005

Villamayor-Tomas, S. 2014b. Adaptive irrigation management in drought contexts: institutional robustness and cooperation in the Riegos del Alto Aragon project (Spain). Pages 197-215 in A. Bhaduri, J. Bogardi, J. Leentvaar, and S. Marx, editors. The global water system in the Anthropocene: challenges for science and governance. Springer, Cham, Switzerland.

Villamayor-Tomas, S. 2018a. Disturbance features, coordination and cooperation: an institutional economics analysis of adaptations in the Spanish irrigation sector. Journal of Institutional Economics 14(3):501-526. https://doi.org/10.1017/ $\underline{\mathrm{S} 1744137417000285}$

Villamayor-Tomas, S. 2018b. Polycentricity in the water-energy nexus: a comparison of polycentric governance traits and implications for adaptive capacity of water user associations in Spain. Environmental Policy and Governance 28(4):252-268. https://doi.org/10.1002/eet.1813

Villamayor-Tomas, S., and G. García-López. 2017. The influence of community-based resource management institutions on adaptation capacity: a large-n study of farmer responses to climate and global market disturbances. Global Environmental Change 47:153-166. https://doi.org/10.1016/j.gloenvcha.2017.10.002

Vis, B. 2012. The comparative advantages of fsQCA and regression analysis for moderately large-N analyses. Sociological Methods and Research 41(1):168-198. https://doi. org/10.1177/0049124112442142

Ward, J. H. Jr. 1963. Hierarchical grouping to optimize an objective function. Journal of the American Statistical Association 58(301):236-244. https://doi.org/10.1080/01621459.1963.10500845

Young, O. R. 2010. Institutional dynamics: resilience, vulnerability and adaptation in environmental and resource regimes. Global Environmental Change 20(3):378-385. https://doi. org/10.1016/j.gloenvcha.2009.10.001 


\section{Appendix 1}

Figure A1.1 Location of RAA irrigation project

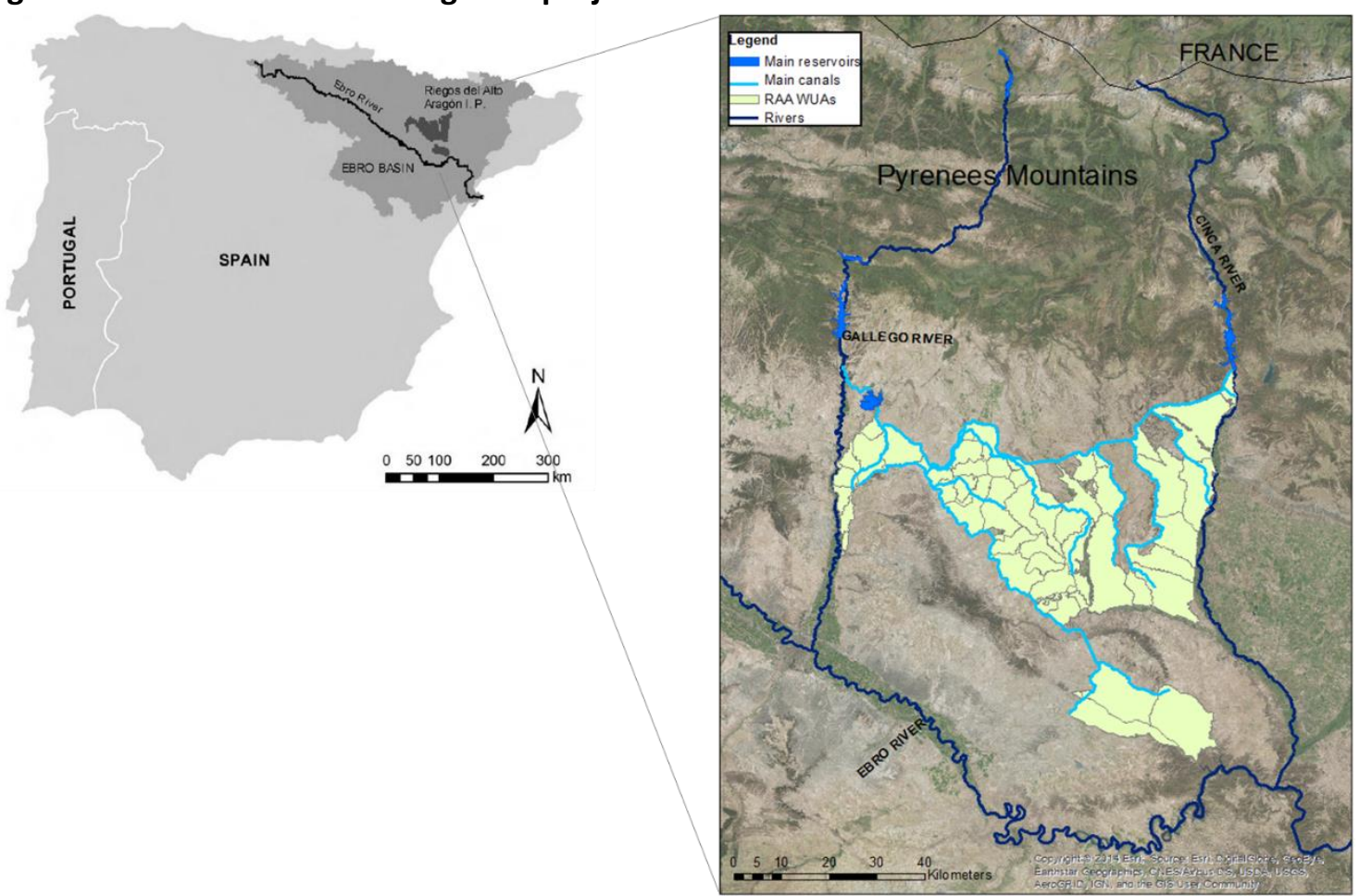

Sources: Esri (2014, https://www.arcgis.com), Gobierno de Aragon (https://idearagon.aragon.es/portal/), and General Association of Riegos del Alto Aragon (GCRAA).

Table A1.1 Univariate sample test of total reservoir water entries (October to September)

\begin{tabular}{|c|c|c|c|c|}
\hline Years & $\begin{array}{l}\text { Total } \\
\text { availability } \\
\left(\mathrm{hm}^{3}\right)\end{array}$ & $\begin{array}{l}\text { Change (vs. } \\
\text { 1971-2003 } \\
\text { series) }\end{array}$ & T statistic ${ }^{\S}$ & $\begin{array}{l}\text { Difference (vs. sum } \\
\text { of water use rights) }\end{array}$ \\
\hline 1971-2003 & 1,640 & & & \\
\hline 2004 & 1,915 & $+17 \%$ & $-3.5^{* * *}$ & $+26 \%$ \\
\hline 2005 & 685 & $-60 \%$ & $12.11^{* * *}$ & $-55 \%$ \\
\hline 2006 & 1,186 & $-28 \%$ & $5.74 * * *$ & $-22 \%$ \\
\hline 2007 & 1,673 & $+2 \%$ & -0.42 & $+10 \%$ \\
\hline
\end{tabular}


Table A1.2 List, measurements and sources of variables

\begin{tabular}{|c|c|c|c|c|}
\hline \multirow[t]{2}{*}{ CONDITIONS } & \multirow[t]{2}{*}{ DEFINITION } & \multirow[t]{2}{*}{ SOURCE } & \multicolumn{2}{|c|}{ ANALYSIS } \\
\hline & & & $\mathrm{HCA}$ & QCA \\
\hline \multicolumn{5}{|l|}{ Outcome } \\
\hline $\begin{array}{l}\text { Drought } \\
\text { adaptation }\end{array}$ & $\begin{array}{l}\text { Difference between irrigation performance index in } \\
2005 \text { minus in } 2004 \text { (see Box A } 1.2 \text { for details on index) }\end{array}$ & $\begin{array}{l}\text { DGA } \\
\text { CGRAA }\end{array}$ & & $x$ \\
\hline \multicolumn{5}{|c|}{ Biophysical conditions } \\
\hline Irrigable area* & Irrigated area (hectares) in the irrigation system & $\begin{array}{l}\text { DGA } \\
\text { CGRAA }\end{array}$ & $\mathrm{X}$ & \\
\hline Summer crops & $\begin{array}{l}\text { Percentage of area in an irrigation system that is } \\
\text { planted with summer crops (higher water demand) }\end{array}$ & $\begin{array}{l}\text { DGA } \\
\text { CGRAA }\end{array}$ & $\mathrm{X}$ & \\
\hline \multicolumn{5}{|c|}{ Technological conditions } \\
\hline Piped canals & $\begin{array}{l}\text { Percentage of the irrigable area in a system that relies } \\
\text { on tubed conveyance systems }\end{array}$ & Survey & $\mathrm{x}$ & \\
\hline Sprinkler & $\begin{array}{l}\text { Percentage of the irrigable area in a system that uses } \\
\text { sprinkler irrigation technology }\end{array}$ & Survey & $\mathrm{x}$ & \\
\hline $\begin{array}{l}\text { Technology } \\
\text { heterogeneity }\end{array}$ & Fractionalization index based on "Sprinkler" variable & Survey & $\mathrm{x}$ & \\
\hline \multicolumn{5}{|c|}{ Social and political conditions } \\
\hline Age of WUA* & Year that the irrigation association was constituted & CGRAA & $x$ & \\
\hline Retired farmers & $\begin{array}{l}\text { Percentage of irrigable area in a system that is } \\
\text { cultivated by retired farmers ( }>65 \text { year old) }\end{array}$ & \begin{tabular}{|l|} 
DGA \\
CGRAA
\end{tabular} & $\mathrm{X}$ & \\
\hline $\begin{array}{l}\text { Average farm } \\
\text { size* }\end{array}$ & Average farm size & CGRAA & $\mathrm{x}$ & \\
\hline Political overlap & $\begin{array}{l}\text { Does at least } 90 \% \text { of the irrigation system fall within } \\
\text { the boundaries of a single municipality? }\end{array}$ & $\begin{array}{l}\text { DGA } \\
\text { CGRAA }\end{array}$ & $\mathrm{x}$ & \\
\hline $\begin{array}{l}\text { Political } \\
\text { heterogeneity }\end{array}$ & $\begin{array}{l}\text { Fractionalization index based on "Political overlap" } \\
\text { variable }\end{array}$ & \begin{tabular}{|l|} 
DGA \\
CGRAA \\
\end{tabular} & $\mathrm{x}$ & \\
\hline \multicolumn{5}{|c|}{ Institutional conditions } \\
\hline Rent & $\begin{array}{l}\text { Percentage of irrigable area in a system that is } \\
\text { cultivated by a renter (of that land) }\end{array}$ & Survey & $\mathrm{X}$ & \\
\hline $\begin{array}{l}\text { Property } \\
\text { heterogeneity }\end{array}$ & Fractionalization index based on "Rental" variable & Survey & $\mathrm{X}$ & \\
\hline Demand irrigation & $\begin{array}{l}\text { Does the association use a demand (metered system) } \\
\text { or a request (water is requested and then guard or } \\
\text { farmers allocate it) allocation system? }\end{array}$ & Survey & $\mathrm{x}$ & \\
\hline Guard & Does the association have a field guard? & Survey & $\mathrm{X}$ & \\
\hline \multicolumn{5}{|c|}{ Adaptation institutions } \\
\hline $\begin{array}{l}\text { Monitoring } \\
\text { (generic adaptation) }\end{array}$ & $\begin{array}{l}\text { Did the WUA reinforced monitoring during the } 2005 \\
\text { drought? }\end{array}$ & Survey & & $x$ \\
\hline $\begin{array}{l}\text { Participation } \\
\text { (generic adaptation) }\end{array}$ & $\begin{array}{l}\text { Percentage of farmers who assisted, on average, to } \\
\text { the assemblies celebrated in } 2005 \text { (drought year), as } \\
\text { measured by the hectares represented }\end{array}$ & Survey & & $x$ \\
\hline $\begin{array}{l}\text { Transfers } \\
\text { (specific adaptation) }\end{array}$ & $\begin{array}{l}\text { Number of hectares benefited by water transfers (this } \\
\text { option is only available during droughts as part of the } \\
\text { quota system: only farmers with cultivated land in } \\
\text { more than one irrigation system have that option) }\end{array}$ & GCRAA & & $x$ \\
\hline
\end{tabular}

Note: DGA: Government of Aragon; GCRAA: General Association of Riegos del Alto Aragon.

* We used the LN transformation of these variables to avoid scale effects in continuous variables 
Table A1.3 Descriptive statistics of variables

\begin{tabular}{|l|l|l|l|l|}
\hline & Mean & St. Dev. & Min. & Max. \\
\hline Outcome & -23.9 & 13.9 & -49.8 & 7.5 \\
\hline Biophysical conditions & & & & \\
\hline Soil WHC (\% of total has) & 47.6 & 26.6 & 0 & 97 \\
\hline Irrigable area (has) & 2,432 & 1,871 & 249 & 9,309 \\
\hline Summer crops (\% of total has) & 75.2 & 10.5 & 43.3 & 90.5 \\
\hline Technological conditions & & & & \\
\hline Sprinkler (\% of has) & 22.9 & 33.3 & 0 & 100 \\
\hline Piped canals (\% of total has) & 39.5 & 49.5 & 0 & 100 \\
\hline Technology heterogeneity (index) & 0.19 & 0.21 & 0 & 0.89 \\
\hline Socio-political conditions & & & & \\
\hline Age of WUA (years) & 40 & 19.7 & 7 & 80 \\
\hline Retired farmers (\% of total has) & 22.7 & 8.6 & 5.5 & 38.9 \\
\hline Average farm size (has) & 17.5 & 6.9 & 5.9 & 33.4 \\
\hline Political overlap (\% of total has) & 52.6 & 50.6 & 0 & 100 \\
\hline Political heterogeneity (index) & 0.24 & 0.23 & 0 & 0.70 \\
\hline Institutional conditions & & & & \\
\hline Rent (\% of land) & 40.3 & 13.4 & 17.1 & 90 \\
\hline Property heterogeneity (index) & 0.45 & 0.07 & 0.19 & 0.5 \\
\hline Demand irrigation (\% of total has) & 15.7 & 37 & 0 & 100 \\
\hline Guard (1,0) & 0.79 & 0.41 & 0 & 1 \\
\hline Monitoring (1,0)* & 0.29 & 0.46 & 0 & 1 \\
\hline Participation (\% of total has)* & 30.2 & 21.9 & 3 & 100 \\
\hline Transfers (\% of total has)* & 3.1 & 2.3 & 0 & 7.8 \\
\hline
\end{tabular}

*During droughts (i.e., 2005 drought). Raw data (i.e.,before the QCA calibration). 


\section{Box A1.1 Survey questions delivered to representatives of WUAs and used in this study}

¿Could you indicate which soils dominate in the irrigable land with full irrigation rights of your irrigation system in percentage?*

\begin{tabular}{|l|c|}
\hline «Sasos» & $\%$ \\
\hline «Suelos Fuertes» & $\%$ \\
\hline Saline soils & $\%$ \\
\hline
\end{tabular}

Which conveyance infrastructure dominates in your irrigation system in $\%$ of the area irrigated?

\begin{tabular}{|l|c|}
\hline Unpaved ditches & $\%$ \\
\hline Paved ditches & $\%$ \\
\hline Flumes (elevated ditches) & $\%$ \\
\hline Pipes & $\%$ \\
\hline
\end{tabular}

Which irrigation infrastructure dominates in your irrigation system in $\%$ of the area irrigated?

\begin{tabular}{|l|c|}
\hline Flood irrigation & $\%$ \\
\hline Sprinkler irrigation & $\%$ \\
\hline Drip irrigation & $\%$ \\
\hline
\end{tabular}

Which land tenure regime dominates in your irrigation system in $\%$ of the area irrigated?

\begin{tabular}{|l|c|}
\hline Cultivated by owners & $\%$ \\
\hline Rented & $\%$ \\
\hline Sharecropping & $\%$ \\
\hline Other & $\%$ \\
\hline
\end{tabular}

Which water allocation system/s is/are used in your irrigation system $\%$ of the area irrigated?

\begin{tabular}{|l|c|}
\hline Turn & $\%$ \\
\hline Command/requests & $\%$ \\
\hline Demand (metered) & $\%$ \\
\hline
\end{tabular}

Does your WUA count on a patrolling guard or someone under the control of the management board who carries that task?

Yes

No

Did the guard reinforce patrolling during the 2005 drought?

Yes

Which percentage of the irrigable land did the people who attended the assembly meetings represent in 2005?.Please check the meeting minutes of the meetingif necessary to double-check the numbers.

\begin{tabular}{|l|l|l|l|}
\hline & Month of the meeting & Number of attendants & Percentage of land represented \\
\hline 2005 & $\rightarrow$ & - & $\%$ \\
& $\rightarrow$ & & \\
& $\rightarrow$ & & \\
$\%$ & & & \\
$\%$
\end{tabular}

Note: The original questions were in Spanish

* "Sasos" is the colloquial name used in the area for Xerosol Calcic soils, which tend to have low available water holding capacity (AWHC) and high infiltration. "Suelos Fuertes" correspond to Fluvisol Eutric soils, which have poor drainage but high AWHC. 
Questions to public officials from Ebro Water Agency (2 interviews)

- Is there a protocol for water allocation during droughts that affects the RAA project?

- How does the Ebro Water Agency support the GCRAA during droughts (e.g., for the implementation of the quota policy)?

- Why have some WUAs engaged in infrastructure modernization projects? Why do you think many of them are Asian type of WUAs?

Questions to members of GCRAA management board (5 interviews)

- Which are the main measures taken at the RAA project level to cope with droughts?

- What is the history behind those measures?

- Which measures do WUAs in the RAA project use to cope with droughts?

- If you were to group the WUAs in the RAA project, how would you do it? Based on which features? Would you agree with our classification of WUAs into types?

- Which kinds of farmers tend to use the transfer system? Why do you think the American type of WUAs tend to rely on transfers during droughts?

- Why have some WUAs engaged in infrastructure modernization projects? Why do you think many of them are Asian type of WUAs?

- What in your experience explains farmer attendance to assembly meetings?

- Why in your experience some WUAs do not have guards and/or do not strengthen monitoring during droughts? 
The calculation of the irrigation performance variable is derived from the integration of meteorological, crop and water supply data at the irrigation system level. Monthly meteorological data were obtained from a series of weather stations that are distributed across the area of study and managed by the Spanish Meteorological Agency (AEMET). Yearly crop data at the farm level were obtained from the Regional Government of Aragon (DGA). Data on water supplied to the irrigation systems were obtained from the GCRAA. Another important source of data to calculate the performance variable was a 2004-2007 series of digital maps including the limits of the irrigation systems and the farms within each system. The maps were obtained from the DGA and the GCRAA and constituted the basis to integrate the meteorological, crop and water availability data. A geographic information systems software (ArcGIS 10.0) was used for that purpose.

The performance index was selected as an indicator of irrigation performance for three reasons: It is the result of an standardization effort led by FAO's International Program for Technology and Research in Irrigation and Drainage (IPTRID); it does not require field data collection beyond the use of publicly available meteorological and crop data; and it has been previously used to characterize irrigation performance in Mediterranean environments (Salvador et al. 2011).

ARIS $=\frac{\text { Irrigated Water }}{\text { Crop Water Needs }}=\frac{\text { Irrigated Water }}{\sum_{i}^{k}\left(N H n^{*} h a\right)_{i}}$

Where:

$\mathrm{i}=$ specific crop; $\mathrm{k}=$ number of different crops in the irrigation system; $\mathrm{NHn}=$ Net Crop Water Needs (in $\mathrm{m} 3$ ); ha $=$ hectares

The most important factors that condition $\mathrm{NHn}$ are the crop evapotranspiration (ETc) and the amount of rainfall that can be effectively used by the crop (PE) (Tejero 2003). Following Allen et al. (1998), ETc was obtained from multiplying a crop water coefficient (Kc) and a potential evapotranspiration coefficient (ETO):

$\mathrm{ETC}=\mathrm{ETO} * \mathrm{Kc}$

$\mathrm{Kc}$ is a theoretical index of the water that a crop needs depending mostly on the species and life cycle stage (Allen et al. 1998). ETO measures the amount of surface water that is removed to the atmosphere due to plant transpiration or direct surface evaporation in a hypothetical reference surface of grass with an assumed crop height of $0.12 \mathrm{~m}$, and a moderately dry soil and radiance reflectance (Allen et al. 1998).

Although the FAO provides Kc values of reference on major crops across climatic regions, it has been recommended using site specific Kc values whenever available (Allen et al. 1998). Monthly Kc values of the dominant crops in the area of study in 1995 were obtained from Martínez-Cob et al. (1998) and used as reference for the period under study. The ETO was calculated following the Hargreaves method, as adapted to the study area by Tejero (2003). Finally, monthly total rainfall data was transformed into PE measures following the method recommended bv the Soil Conservation Service (SCS) (Dastane 1978. cited in Teiero 2003). 


\section{Literature cited}

Allen, R. G., L. S. Pereira, D. Raes, and M. Smith. 1998. Crop evapotranspiration - Guidelines for computing crop water requirements . Page Irrigation and Drainage. FAO .

Martinez-Cob, A., J. M. Faci, and A. Bercero Bercero. 1998. Evapotranspiracion y Necesidades de Riego de los Principales Cultivos en las Comarcas de Aragón. Institución Fernando el Católico (C.S.I.C), Zaragoza .

Moratiel, R., and A. Martínez-Cob. 2013. Evapotranspiration and crop coefficients of rice (Oryza sativa L.) under sprinkler irrigation in a semiarid climate determined by the surface renewal method. Irrigation Science 31(3):411-422.

Salvador, R., A. Martínez-Cob, J. Cavero, and E. Playán. 2011. Seasonal on-farm irrigation performance in the Ebro basin (Spain): Crops and irrigation systems. Agricultural Water Management 98(4):577-587.

Tejero, M. 2003. Cálculo de la Variabilidad Temporal de las Necesidades Hídricas de los Cultivos en las Comarcas de Aragón . Estación Experimental de Aula Dei, C.S.I.C., Zaragoza. 


\section{Appendix 2}

In this appendix, we explain the main steps of the Qualitative Comparative Analysis.

Table A2.1 Raw data matrix

\begin{tabular}{|c|c|c|c|c|c|}
\hline SYSTEM & CLUSTER & TRANSFERS & PARTICIPATION & MONITORING & $\begin{array}{c}\text { DIFF. DROUGHT } \\
\text { PERFORMANCE } \\
\text { (i.e., DROUGTH } \\
\text { ADAPTATION) }\end{array}$ \\
\hline ALBERO BAJO & 1 & 2,6 & 60 & 0 & 7,5 \\
\hline ALCALA DE GURREA & 1 & 0,0 & 62 & 0 & 3,3 \\
\hline ALMUDEVAR & 1 & 0,9 & 85 & 0 & $-26,3$ \\
\hline BARBUES & 1 & 0,2 & 91 & 0 & $-31,0$ \\
\hline EL TEMPLE & 1 & 4,1 & 65 & 0 & $-45,1$ \\
\hline GRAÑEN FLUMEN & 1 & 1,9 & 35 & 0 & $-19,9$ \\
\hline JOAQUIN COSTA & 1 & 0,0 & 23 & 1 & $-49,6$ \\
\hline LALUEZA & 1 & 7,6 & 25 & 0 & $-32,0$ \\
\hline LANAJA & 1 & 3,8 & 60 & 1 & $-18,9$ \\
\hline PIRACES & 1 & 2,6 & 70 & 0 & $-21,6$ \\
\hline SANGARREN & 1 & 0,6 & 27 & 0 & $-19,8$ \\
\hline TARDIENTA & 1 & 3,2 & 20 & 1 & $-18,1$ \\
\hline TORRALBA & 1 & 0,9 & 65 & 0 & $-32,2$ \\
\hline VALFONDA & 1 & 3,4 & 45 & 0 & $-32,5$ \\
\hline VICIEN & 1 & 0,0 & 90 & 0 & $-45,7$ \\
\hline ALCONADRE & 0 & 3,7 & 84 & 0 & $-10,9$ \\
\hline CANDASNOS & 0 & 0,0 & 77 & 0 & $-29,7$ \\
\hline CARTUJA-SAN JUAN & 0 & 2,2 & 31 & 0 & $-30,8$ \\
\hline LA SABINA & 0 & 6,6 & 25 & 0 & $-21,6$ \\
\hline LAS ALMACIDAS & 0 & 2,6 & 80 & 1 & $-25,7$ \\
\hline LASESA & 0 & 7,7 & 22 & 1 & $-24,9$ \\
\hline SAN MIGUEL & 0 & 3,0 & 78 & 0 & $-34,1$ \\
\hline SAN PEDRO & 0 & 7,8 & 40 & 1 & $-17,2$ \\
\hline SANTA CRUZ & 0 & 3,6 & 75 & 1 & $-32,5$ \\
\hline VAL DE ALFERCHE & 0 & 2,9 & 40 & 0 & $-10,3$ \\
\hline ALMUNIENTE & 1 & 0,0 & 30 & 1 & $-36,0$ \\
\hline CALLEN & 1 & 5,2 & 65 & 0 & 1,0 \\
\hline LLANOS DE CAMARERA & 1 & 2,2 & 65 & 0 & $-22,8$ \\
\hline N1 CANAL DEL CINCA & 1 & 1,7 & 24 & 0 & 4,0 \\
\hline SAN JUAN & 1 & 3,8 & 40 & 0 & $-14,3$ \\
\hline TORRES DE BARBUES & 1 & 3,0 & 84 & 0 & $-48,5$ \\
\hline COLLARADA 2 & 0 & 4,5 & 85 & 1 & $-30,9$ \\
\hline ORILLENA & 0 & 4,1 & 21 & 0 & $-35,5$ \\
\hline SECTOR VII FLUMEN & 0 & 2,6 & 26 & 0 & $-30,2$ \\
\hline SECTOR VIII MONEGROS & 0 & 3,4 & 24 & 0 & $-24,7$ \\
\hline SECTOR X FLUMEN & 0 & 6,6 & 40 & 1 & $-16,8$ \\
\hline SODETO-ALBERUELA & 0 & 6,2 & 35 & 0 & $-8,1$ \\
\hline
\end{tabular}

In QCA parlance, Table A2.1 represents the "raw data matrix", encompassing the available empirical evidence that will be used for analysis. The lines of a raw data matrix represent the "cases", whereas the column represent the "measures" - the empirical evidence, in whatever form it may come. In light of the binary nature of some of the measures ("Cluster" and "Monitoring") involved in the analysis, we opt for a crisp-set QCA (csQCA).

The first step in a QCA is called "calibration" and consists in translating measures into membership scores (whether the cases at stake belong or do not belong to those "sets" 
representing the conditions for analysis). Since the analysis relies on crisp sets (and not on fuzzy sets or categorial variables), membership scores will be either 1 (full membership: case belongs to the set) or 0 (full membership in the negation of the set: case does not belong to the set).

How membership scores are obtained from the four variables above depends on the nature of the variable at hand. The variables CLUSTER and MONITORING are binary, and thus inherently represent memberships in particular sets. The variables TRANSFERS, PARTICIPATION and DROUGHT ADAPTATION are instead numeric and represent quantities. Converting them into membership scores requires setting thresholds that reflect qualitative changes between cases, in line with the definition of each specific set. With this in mind, thresholds for TRANSFERS, PARTICIPATION andDROUGHT ADAPTATION were set at 3\%, 50\%, and $-25 \%$, respectively.

Figure A2.1 - Calibration of non-binary measures

TRANSFERS

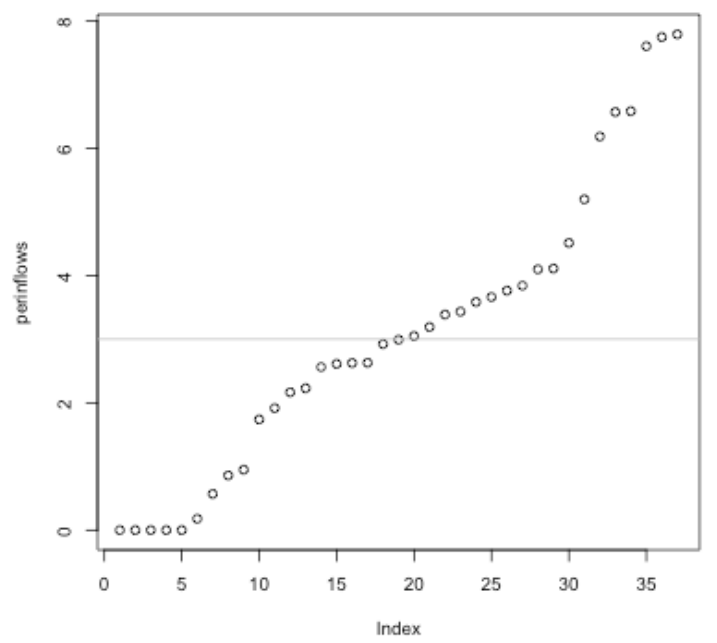

OUTCOME

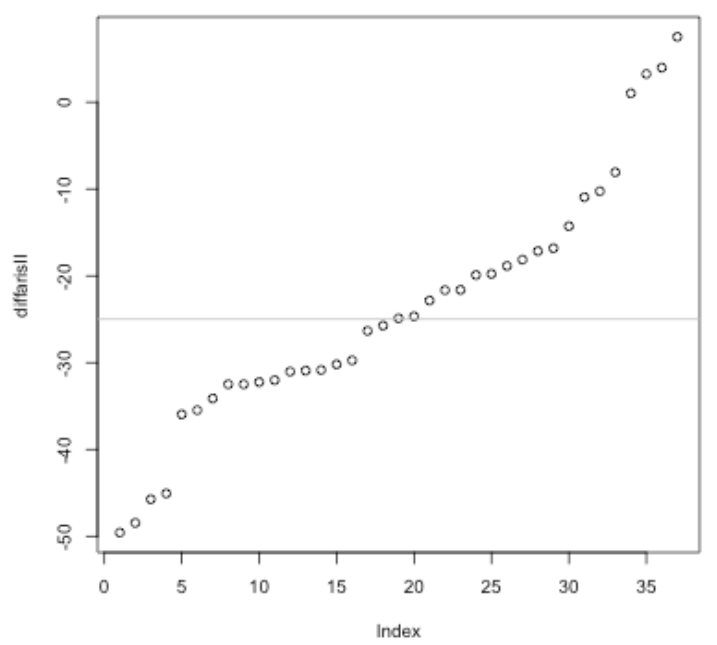

PARTICIPATION

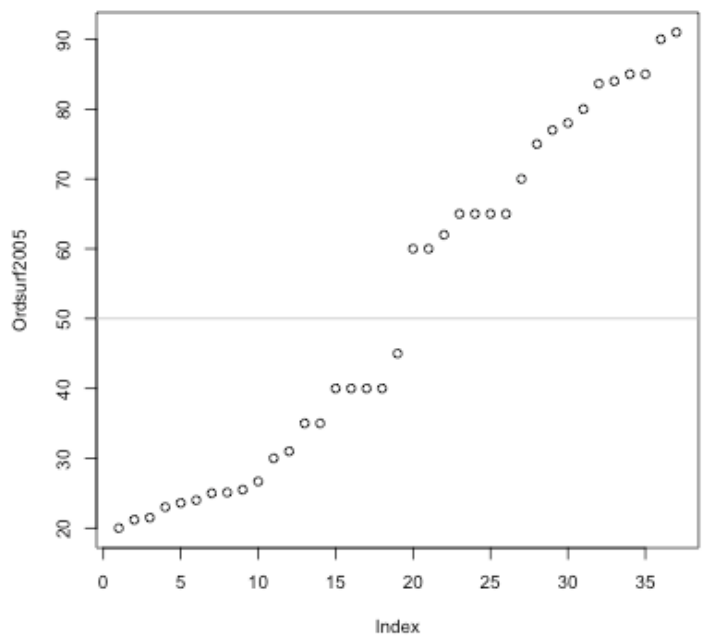

Note that these thresholds are rather close to the median value for each measures, thus ensuring sufficient variation in the resulting sets, yet they were chosen for being substantively meaningful, and not for their relation to the median value. In the case of TRANSFERS, 3\% may 
look small but it is considerable considering that the transfer institution was designed as a measure to tweak the quota allocations at the margins. In the case of PARTICIPATION, $50 \%$ of participation (as per hectares represented) made sense, given that decisions in the WUA assemblies are made based on the number of hectares represented. DROUGHT ADAPTATION is used here as our outcome ("OUTCOME" from now on). In the present context, a drop in irrigation performance smaller than $25 \%$ can be considered a success (i.e., successful drought adaptation), given that (1) the drought meant a reduction in available water by $60 \%$, and (2) farmers consider that up to $30 \%$ of water stress is not severely detrimental for production (although this varies with agronomic conditions). Irrigation systems with a differential in irrigation performance higher than $-25 \%$ are therefore members of OUTCOME (membership score $=1$ ), while systems with differentials below $-25 \%$ are not (membership score $=0$ ).

Table A2.2 Membership scores

\begin{tabular}{|c|c|c|c|c|c|}
\hline & CLUSTER & TRANSFERS & PARTICIPATION & MONITORING & OUTCOME \\
\hline ALBERO BAJO & 1 & 0 & 1 & 0 & 1 \\
\hline ALCALA DE GURREA & 1 & 0 & 1 & 0 & 1 \\
\hline ALMUDEVAR & 1 & 0 & 1 & 0 & 0 \\
\hline BARBUES & 1 & 0 & 1 & 0 & 0 \\
\hline EL TEMPLE & 1 & 1 & 1 & 0 & 0 \\
\hline GRAÑEN FLUMEN & 1 & 0 & 0 & 0 & 1 \\
\hline JOAQUIN COSTA & 1 & 0 & 0 & 1 & 0 \\
\hline LALUEZA & 1 & 1 & 0 & 0 & 0 \\
\hline LANAJA & 1 & 1 & 1 & 1 & 1 \\
\hline PIRACES & 1 & 0 & 1 & 0 & 1 \\
\hline SANGARREN & 1 & 0 & 0 & 0 & 1 \\
\hline TARDIENTA & 1 & 1 & 0 & 1 & 1 \\
\hline TORRALBA & 1 & 0 & 1 & 0 & 0 \\
\hline VALFONDA & 1 & 1 & 0 & 0 & 0 \\
\hline VICIEN & 1 & 0 & 1 & 0 & 0 \\
\hline ALCONADRE & 0 & 1 & 1 & 0 & 1 \\
\hline CANDASNOS & 0 & 0 & 1 & 0 & 0 \\
\hline CARTUJA-SAN JUAN & 0 & 0 & 0 & 0 & 0 \\
\hline LA SABINA & 0 & 1 & 0 & 0 & 1 \\
\hline LAS ALMACIDAS & 0 & 0 & 1 & 1 & 0 \\
\hline LASESA & 0 & 1 & 0 & 1 & 1 \\
\hline SAN MIGUEL & 0 & 1 & 1 & 0 & 0 \\
\hline SAN PEDRO & 0 & 1 & 0 & 1 & 1 \\
\hline SANTA CRUZ & 0 & 1 & 1 & 1 & 0 \\
\hline VAL DE ALFERCHE & 0 & 0 & 0 & 0 & 1 \\
\hline ALMUNIENTE & 1 & 0 & 0 & 1 & 0 \\
\hline CALLEN & 1 & 1 & 1 & 0 & 1 \\
\hline LLANOS CAMARERA & 1 & 0 & 1 & 0 & 1 \\
\hline N1 CANAL DEL CINCA & 1 & 0 & 0 & 0 & 1 \\
\hline SAN JUAN & 1 & 1 & 0 & 0 & 1 \\
\hline TORRES DE BARBUES & 1 & 1 & 1 & 0 & 0 \\
\hline COLLARADA 2 & 0 & 1 & 1 & 1 & 0 \\
\hline ORILLENA & 0 & 1 & 0 & 0 & 0 \\
\hline SECTOR VII FLUMEN & 0 & 0 & 0 & 0 & 0 \\
\hline SECTOR VIII MONEGROS & 0 & 1 & 0 & 0 & 1 \\
\hline SECTOR X FLUMEN & 0 & 1 & 0 & 1 & 1 \\
\hline SODETO-ALBERUELA & 0 & 1 & 0 & 0 & 1 \\
\hline
\end{tabular}


The next step in a standard analysis consists in testing whether any of the conditions at stake represent an individually necessary condition for the presence of the outcome. Ideally, a condition is necessary (and fully consistently so) if the OUTCOME is never observed without it. Full consistency is not required, though. Conventionally, conditions are deemed necessary if their consistency score for necessity is above 0.9. In a crisp-set setting, this is the same as saying that less than ten percent of the cases are allowed to contradict the necessity claim. It is also important that a condition is not trivially necessary, i.e., that it corresponds to a set so large as to include almost all cases - making counterfactual analysis virtually impossible.

Table A2.3 Consistency and coverage scores for necessity

\begin{tabular}{|l|l|l|}
\hline & Consistency & Coverage \\
\hline CLUSTER & 0.579 & 0.524 \\
\hline PARTICIPATION & 0.368 & 0.389 \\
\hline TRANSFERS & 0.579 & 0.611 \\
\hline STR_MONITORING & 0.263 & 0.5 \\
\hline
\end{tabular}

Consistency and coverage scores for necessity are presented in Table A2.3. As one can see, no condition is individually necessary. If any of them would be necessary, a very high coverage score (well above 0.75 ) would hint at a trivially necessary condition. This is however not the case.

The analysis of necessity is then followed by the analysis of sufficiency, which consists of the analysis of the truth table, followed by logical minimization. Paths with a consistency score equal or higher than 0.75 are considered sufficient for the outcome. Paths have been sorted based on the inclusion score.

Table A2.4 Truth table for analysis of sufficiency for successful drought adaptation (OUTCOME=1)

\begin{tabular}{|l|l|l|l|l|l|l|l|}
\hline TRANSFERS & PARTICIPATION & MONITORING & CLUSTER & OUT & $\mathrm{n}$ & incl & PRI \\
\hline 0 & 0 & 0 & 1 & 1 & 3 & 1.000 & 1.000 \\
\hline 1 & 0 & 1 & 0 & 1 & 3 & 1.000 & 1.000 \\
\hline 1 & 0 & 1 & 1 & 1 & 1 & 1.000 & 1.000 \\
\hline 1 & 1 & 0 & 0 & 1 & 1 & 1.000 & 1.000 \\
\hline 1 & 1 & 1 & 1 & 1 & 1 & 1.000 & 1.000 \\
\hline 1 & 0 & 0 & 0 & 1 & 4 & 0.750 & 1.000 \\
\hline 0 & 1 & 0 & 1 & 0 & 8 & 0.500 & 0.500 \\
\hline 0 & 0 & 0 & 0 & 0 & 3 & 0.333 & 0.333 \\
\hline 1 & 0 & 0 & 1 & 0 & 3 & 0.333 & 0.333 \\
\hline 1 & 1 & 0 & 1 & 0 & 3 & 0.333 & 0.333 \\
\hline 0 & 0 & 1 & 1 & 0 & 2 & 0.000 & 0.000 \\
\hline 0 & 1 & 0 & 0 & 0 & 2 & 0.000 & 0.000 \\
\hline 0 & 1 & 1 & 0 & 0 & 1 & 0.000 & 0.000 \\
\hline 1 & 1 & 1 & 0 & 0 & 2 & 0.000 & 0.000 \\
\hline 0 & 0 & 1 & 0 & $?$ & 0 & - & - \\
\hline 0 & 1 & 1 & 0 & $?$ & 0 & - & - \\
\hline
\end{tabular}

Note 1: The "OUT" column indicates whether the path represents a sufficient condition for the outcome set. The " $n$ " column indicates how many cases populate the respective path. The "incl" column indicates the "inclusion score", that is, the consistency score for sufficiency for the path. Paths with a consistency score equal or higher than 0.75 are considered sufficient for the outcome. Paths have been sorted based on the inclusion score. Note 2: In light grey the paths included in the minimization. 
A QCA standard analysis encompasses three types of solutions: complex, intermediate, and parsimonious. The difference between them lies in the use of logical minimization, and in the introduction of assumptions concerning logical remainders. Specifically, complex solutions involve no logical minimization and is equal to the union of all sufficient paths from the truth table; intermediate solutions involve logical minimization, but only among observed, consistent paths. Parsimonious solutions involve logical minimizations and include logical remainders, implying assumptions concerning those paths that were not observed. All three types of solutions have their own merits and drawbacks. As a standard of good practice, all three solutions are reported. This is a sign of transparency and allows for an informed choice on which solution to rely on when interpreting the results. The complex solution is reported below in Table A2.5. It has an overall consistency score of 0.923 and a coverage score of 0.632 . The intermediate solution is reported in the article's main text and will not be duplicated here. The parsimonious solution is equivalent to the intermediate solution, since none of the logical remainder is capable of minimizing the solution formula any further.

Table A2.5 Complex solution to successful drought adaptation (OUTCOME=1)

\begin{tabular}{|l|l|}
\hline & $\begin{array}{l}\text { Complex solution } \\
\text { CONS, COV: 0.923, 0.632 }\end{array}$ \\
\hline Cluster-independent & -- \\
\hline Asian model (CLUSTER) & $\begin{array}{l}\text { transfers*participation*monitoring } \\
\text { TRANSFERS* participation*MONITORING } \\
\text { TRANSFERS*PARTICIPATION*MONITORING }\end{array}$ \\
\hline $\begin{array}{l}\text { American model } \\
\text { (cluster) }\end{array}$ & $\begin{array}{l}\text { TRANSFERS*participation*MONITORING } \\
\text { TRANSFERS*PARTICIPATION*monitoring } \\
\text { TRANSFERS*participation*monitoring }\end{array}$ \\
\hline
\end{tabular}

QCA is characterized by asymmetrical causation. This implies that membership in the negation of the outcome requires its own analysis and cannot be inferred from the solution formula explaining membership in the outcome set. In the context of the present analysis, this implies that explaining unsuccessful drought adaptation requires its own analyses of necessity and sufficiency. Below, the reader can find the consistency and coverage score for necessity for all conditions at stake, the truth table for the negation of the outcome, and the paths for both the complex and parsimonious solutions (the intermediate is used in the main text).

Table A2.6 Analysis of necessity for unsuccessful drought adaptation (OUTCOME=0)

\begin{tabular}{|l|l|l|}
\hline & Consistency & Coverage \\
\hline CLUSTER & 0.556 & 0.476 \\
\hline PARTICIPATION & 0.611 & 0.611 \\
\hline TRANSFERS & 0.389 & 0.389 \\
\hline STR_MONITORING & 0.278 & 0.5 \\
\hline
\end{tabular}

No condition is individually necessary for the outcome. 
Table A2.7 Truth table for analysis of sufficiency for unsuccessful drought adaptation (OUTCOME=0)

\begin{tabular}{|l|l|l|l|l|l|l|l|}
\hline TRANSFERS & PARTICIPATION & MONITORING & CLUSTER & OUT & $\mathrm{n}$ & incl & PRI \\
\hline 0 & 0 & 1 & 1 & 1 & 2 & 1.000 & 1.000 \\
\hline 0 & 1 & 0 & 0 & 1 & 2 & 1.000 & 1.000 \\
\hline 0 & 1 & 1 & 0 & 1 & 1 & 1.000 & 1.000 \\
\hline 1 & 1 & 1 & 0 & 1 & 2 & 1.000 & 1.000 \\
\hline 0 & 0 & 0 & 0 & 0 & 3 & 0.667 & 0.667 \\
\hline 1 & 0 & 0 & 1 & 0 & 3 & 0.667 & 0.667 \\
\hline 1 & 1 & 0 & 1 & 0 & 3 & 0.500 & 0.500 \\
\hline 0 & 1 & 0 & 1 & 0 & 8 & 0.250 & 0.250 \\
\hline 1 & 0 & 0 & 0 & 0 & 4 & 0.000 & 0.000 \\
\hline 0 & 0 & 0 & 1 & 0 & 3 & 0.000 & 0.000 \\
\hline 1 & 0 & 1 & 0 & 0 & 3 & 0.000 & 0.000 \\
\hline 1 & 0 & 1 & 1 & 0 & 1 & 0.000 & 0.000 \\
\hline 1 & 1 & 0 & 0 & 0 & 1 & 0.000 & 0.000 \\
\hline 1 & 1 & 1 & 1 & 0 & 1 & 0.000 & 0.000 \\
\hline 0 & 0 & 1 & 0 & 0 & 0 & - & - \\
\hline 0 & 1 & 1 & 1 & 0 & 0 & - & - \\
\hline
\end{tabular}

Table A2.8 Complex and parsimonious solutions to unsuccessful drought adaptation (OUTCOME=0)

\begin{tabular}{|l|l|l|}
\hline & $\begin{array}{l}\text { Complex solution } \\
\text { CONS, COV: 0.1, } 0.389\end{array}$ & $\begin{array}{l}\text { Parsimonious solution } \\
\text { CONS, COV: 0.1, 0.389 }\end{array}$ \\
\hline $\begin{array}{l}\text { Cluster- } \\
\text { independent }\end{array}$ & -- & transfers*MONITORING \\
\hline $\begin{array}{l}\text { Asian model } \\
\text { (CLUSTER) }\end{array}$ & transfers*participation*MONITORING & -- \\
\hline $\begin{array}{l}\text { American } \\
\text { model } \\
\text { (cluster) }\end{array}$ & $\begin{array}{l}\text { transfers*PARTICIPATION*monitoring } \\
\text { transfers*PARTICIPATION*MONITORING }\end{array}$ & $\begin{array}{l}\text { transfers*PARTICIPATION } \\
\text { PARTICIPATION*MONITORING }\end{array}$ \\
\hline
\end{tabular}

Finally, some considerations are worthwhile concerning the role of CLUSTER in the analysis, introducing an additional differentiation in what would have otherwise been an analysis of OUTCOME as a product of TRANSFERS, PARTICIPATION, and MONITORING. The set-theoretic nature of QCA ensures that, to the extent CLUSTER does not contribute to explaining OUTCOME, it will not appear in the results. It's because of this that some of the paths presented above are cluster-independent. One can think of them as the results of two separate analyses, one addressing CLUSTER cases, the other addressing CLUSTER cases. Each path that is common to both analyses effectively makes the distinction of cases along CLUSTER irrelevant.

Formally, if the truth table would show that

$$
\text { CLUSTER * TRANSFERS * MONITORING }=>\text { OUTCOME }
$$

while also showing that

$$
\text { CLUSTER * TRANSFERS * MONITORING }=>\text { OUTCOME }
$$


Logical minimization would then infer that

TRANSFERS * MONITORING $=>$ OUTCOME

By the same token, all paths that are not cluster-independent would not appear if CLUSTER was not considered. One can see that by replicating the analysis without CLUSTER. The analysis of necessity would not change, since it focuses on individual conditions. The analysis of sufficiency would instead provide the following truth tables (one for OUTCOME, the other one for OUTCOME).

Table A2.9 Truth table for analysis of sufficiency for successful drought adaptation without CLUSTER

\begin{tabular}{|l|l|l|l|l|l|l|}
\hline TRANSFERS & PARTICIPATION & MONITORING & OUT & $\mathrm{n}$ & incl & PRI \\
\hline 1 & 0 & 1 & 1 & 4 & 1.000 & 1.000 \\
\hline 0 & 0 & 0 & 0 & 6 & 0.667 & 0.667 \\
\hline 1 & 0 & 0 & 0 & 7 & 0.571 & 0.571 \\
\hline 1 & 1 & 0 & 0 & 4 & 0.500 & 0.500 \\
\hline 0 & 1 & 0 & 0 & 10 & 0.400 & 0.400 \\
\hline 1 & 1 & 1 & 0 & 3 & 0.333 & 0.333 \\
\hline 0 & 0 & 1 & 0 & 2 & 0.000 & 0.000 \\
\hline 0 & 1 & 1 & 0 & 1 & 0.000 & 0.000 \\
\hline
\end{tabular}

Table A2.10 Truth table for analysis of sufficiency for unsuccessful drought adaptation without CLUSTER

\begin{tabular}{|l|l|l|l|l|l|l|}
\hline TRANSFERS & PARTICIPATION & MONITORING & OUT & $\mathrm{n}$ & incl & PRI \\
\hline 0 & 0 & 1 & 1 & 2 & 1.000 & 1.000 \\
\hline 0 & 1 & 1 & 1 & 1 & 1.000 & 1.000 \\
\hline 1 & 1 & 1 & 0 & 3 & 0.667 & 0.667 \\
\hline 0 & 1 & 0 & 0 & 10 & 0.600 & 0.600 \\
\hline 1 & 1 & 0 & 0 & 4 & 0.500 & 0.500 \\
\hline 1 & 0 & 0 & 0 & 7 & 0.429 & 0.429 \\
\hline 0 & 0 & 0 & 0 & 6 & 0.333 & 0.333 \\
\hline 1 & 0 & 1 & 0 & 4 & 0.000 & 0.000 \\
\hline
\end{tabular}

Solution formulas would respectively be:

M1: TRANSFERS*participation*MONITORING => OUTCOME

and

M1: transfers*MONITORING $=>$ OUTCOME

Note how for OUTCOME the absence of logical remainders and the presence of only one path effectively prevent logical minimization. Complex, intermediate and parsimonious solutions are therefore identical. For OUTCOME, instead, two sufficient paths are available, and they allow for logical minimization, so that the complex and intermediate solution do differ. 
The interesting observation is that both solution formulas above were also part of the solution formulas in the main analysis: they were not lost by adding an additional variable (CLUSTER). More specifically, the solution formula for OUTCOME corresponds to the cluster-independent path identified in the corresponding intermediate solution from the main analysis. The solution formula for OUTCOME appears in the parsimonious solution from the main analysis. Yet, both solutions cover only a tiny fraction of OUTCOME and OUTCOME: four out of 19 and three out of 18 cases, respectively. This corresponds to coverage scores of 0.210 and 0.166 . Including CLUSTER increases coverage scores to 0.632 and 0.389 , respectively. The greater nuance achieved by including CLUSTER, therefore, allows us to explain a much larger proportion of the phenomenon of interest. 